\title{
Evaluation of the Effect of Heat Input and Cooling Rate of Rail Flash-Butt Welding using Finite Element Method Simulation
}

\author{
Henrique Boschetti Pereira ${ }^{1}$ (D) , Edwan Anderson Ariza Echeverri ${ }^{1,2}$ (D) , Luiz Henrique Dias Alves ${ }^{3}$, Hélio Goldenstein ${ }^{1}$ (D) \\ ${ }^{1}$ Universidade de São Paulo, São Paulo, SP, Brasil. \\ ${ }^{2}$ Universidad Tecnológica de Pereira, Pereira, Risaralda, Colombia. \\ ${ }^{3}$ Universidade Federal de Juiz de Fora, Juiz de Fora, MG, Brasil.
}

How to cite: Pereira HB, Echeverri EAA, Alves LHD, Goldenstein H. Evaluation of the effect of heat input and cooling rate of rail flash-butt welding using finite element method simulation. Soldagem \& Inspeção. 2022;27:e2701. https://doi.org/10.1590/0104-9224/SI27.01

\begin{abstract}
Simulations using the finite element method (FEM) were done to understand the effects of heating/cooling rates on the distribution of residual stresses. Two material parameters from rails were used while the boundary conditions remained constant: heat-affected zone size, maximum temperature and heating extraction rate. To complement the analysis, a flash-butt weld of a Premium rail was done with welding parameters adjusted to obtain a narrow HAZ, without forced cooling, to examine the microstructure formed in the critical regions in the web and the edge of the rail foot. The results showed that there was a concentration of vertical residual stresses in the web region, while the presence of horizontal compression residual stresses was mostly superficial in the rail head region. The main result from the simulation sets was that when using two simulation parameters with similar materials (rails) substantially different results were obtained. Metallographic examinations showed that there was no presence of acicular microconstituents (martensite/bainite). In the rail web, proeutectoid ferrite was observed in the central region, cementite in a previous austenitic grain boundary, in the region that reached temperatures close to $A_{c 3}$, and almost complete spheroidization in the region of maximum spheroidization. In contrast, in the rail foot edge region, there was a completely pearlitic microstructure, in the central region and in the zone that reached temperatures close to $A_{C 3}$, and a lower volume of spheroidization in the region where maximum spheroidization is typically observed, probably due to the higher cooling rate in this region.
\end{abstract}

Keywords: Rail; Welding; Flash-butt; FEM; Simulation; Residual stresses.

\section{Avaliação do Efeito do Aporte Térmico e da Taxa de Resfriamento da Soldagem de Topo de Trilho por Meio de Simulação pelo Método dos Elementos Finitos}

\begin{abstract}
Resumo: Simulações pelo método dos elementos finitos (MEF) foram realizadas para entender os efeitos das taxas de aquecimento/resfriamento na distribuição de tensões residuais. Dois parâmetros de material dos trilhos foram usados, enquanto as condições de contorno permaneceram constantes: tamanho da zona afetada pelo calor, temperatura máxima e taxa de extração de aquecimento. Para complementar a análise, foi realizada uma solda de topo por centelhamento de um trilho Premium com parâmetros de soldagem ajustado para obter uma baixa extensão de zona afetada pelo calor, sem resfriamento forçado, para examinar a microestrutura formada nas regiões críticas na alma e no extremo do patim. Os resultados mostraram que houve concentração de tensões residuais verticais na região da alma, enquanto a presença de tensão residual de compressão no sentido horizontal foi predominantemente superficial na região do trilho superior. Ao usar dois parâmetros de simulação de materiais semelhantes (trilhos), os resultados foram substancialmente diferentes. Os exames metalográficos mostraram que não havia presença de microconstituintes aciculares (martensita/bainita). Além disso, foi observada ferrita pro-eutetóide na região central, cementita em contorno de grão austenítico prévio na região próxima a $A_{c 3}$ e esferoidização quase completa na região de sítio de esferoidização máxima da alma. Em contrapartida, na região do extremo do patim, apresentou microestrutura completamente perlítica na região central e próxima a $A_{c 3}$ e menor volume de esferoidização na região de máxima esferoidização, provavelmente devido à maior taxa de resfriamento nesta região.
\end{abstract}

Palavras-chave: Trilho; Soldagem; Flash-butt; FEM; Simulação; Tensões residuais. 


\section{Introduction}

Rail's residual stress levels are a constant safety and industrial issue, leading to rail failures significantly earlier than expected. Residual stress is the set of stresses (shear, tensile, and/or compression) present inside the material without the need for external forces. A structure may contain a stress gradient, but the resultant internal stress must be in equilibrium and equal to zero. These residual stresses will add to external factors, providing a resultant stress that is the sum of external forces with internal stresses [1].

Residual stresses can be introduced either by cold rolling/forming processes, bending stress, thermal stresses, heterogeneous phase transformations, etc. These can be divided into three types of stresses according to the length scale [1]:

- Type $\mathrm{I}$ is classified as the residual macro stresses. This type of residual stress is constant in the volume of several grains, causes appreciable uniform deformations of the crystalline lattice, and it is generated by mechanical, chemical or thermal processes.

- $\quad$ Type II is classified as the micro stresses present in the grain boundaries (a grain or some grains) or stresses present on the micron order $(\mathrm{mm})$. This type of residual stress can originate from a difference in crystallographic orientation or from phase transformations.

- $\quad$ Type III is classified as sub-micro stresses and acts on the atomic scale. It is constant in small areas over small atomic distances. They may be related to dislocations or defects in the crystalline lattice.

Despite the Type II and III residual stresses having a direct influence on those of Type I, only Type I residual stresses will be analyzed in this paper.

Rails are currently joined by welding processes, of which the two most common are thermite welding, which corresponds to $10 \%$ to $20 \%$, and flash-butt welding, which corresponds to $80 \%$ to $90 \%$ [2].

Horizontal fatigue cracks starting at the rail web, mainly due to residual tensile stresses introduced by the welding process, are a common failure process as described by Godefroid et al. [3] and Mousavizade and Farhangi [4].

A failure analysis conducted by Godefroid et al. [3] showed that fatigue cracks nucleate at the center of the weld and propagates horizontally. After horizontal nucleation, the cracks tend to branch towards the rail's upper and/or lower surfaces and may cause a fracture.

The residual stresses can be of such magnitude that they may promote a premature failure, such as a rail failure after a huge transversal crack opening, in which the longitudinal separation of the rail in two parts for $60 \mathrm{~cm}$ occurs mainly due to the presence of tensile residual stresses in the web region. This particular failure analysis by the IPT (Technological Research Institute of São Paulo State - Brazil) occurred in an unwelded rail, with residual stresses present due to the rail manufacturing process [5].

Currently, there is an effort to reduce the heat-affected zone (HAZ) width of flash-butt welding [6-8]. Saita et al. [8] showed a higher wear resistance at the softened region by narrowing the HAZ width. Additionally, to decrease residual tensile stresses in the rail web, they performed a post-weld heat treatment after the welding process.

Recent works [6,7] have also shown that the decrease in HAZ width leads to an improvement in the mechanical properties of Premium and Super Premium pearlitic rails.

The flash-butt welding heat input provides enough energy for phase transformations in the heat-affected zone. Many studies have been carried out with the objective of understanding the microstructure, mainly in the mechanical strength of the rail. The temperature distribution was studied by Weingrill et al. [9], based on simulations and thermocouple measurements. The results showed that the thermal cycle peak temperature reached a maximum of approximately $1355^{\circ} \mathrm{C}$ in the weld center and decreased as the distance to the weld increased.

As the weld heat source and rail geometry itself are complex, finite element analysis is the best way to analyze the residual stresses from a thermal cycle of a welding process.

The studies performed by Haibatollahi and Tehrani [10] presented simulations of residual stresses by the finite element method carried out using Ansys ${ }^{\circledR}$ software. In their simulations, phase transformations were not considered, and residual stresses were only calculated from thermal expansion during the thermal cycles of the welding process. The material parameters used in their simulations came from an AISI 1080 steel, as the authors considered it a material similar to the rail. The thermal and mechanical parameters of the material as a function of the temperature used were obtained [11-13]. One of the results showed that tensile residual stresses are located mainly in the rail web region. The comparison of the simulated and experimental residual stresses, obtained through the hole drilling method, showed that the simulations were very close to the experimental values [10].

The simulations of residual stresses generated by the flash-butt welding process were studied by Cai et al. [14], considering the influence of phase transformations. The finite element code used in the simulation was JWRIAN. Yield strength data for ferrite, austenite, pearlite, and martensite as a function of temperature were used. Young modulus data, thermal conductivity, thermal capacity, heat coefficient, and thermal expansion coefficient varying with temperature were also implemented. The heat source used was $105 \mathrm{~J} / \mathrm{s}$ for $5 \mathrm{~s}$. The cooling curve transformation CCT diagram used was from a U75MnV alloy. Simulation results with and without considering phase transformation were compared to residual stress measurements using the hole drilling method. Different models were compared and the one considering phase transformations presented a better approximation with the values obtained experimentally. Surprisingly, their simulations predicted that the welded joint center had 100\% martensite and that between $10 \mathrm{~mm}$ and $12 \mathrm{~mm}$ there was $70 \%$ martensite and 30\% pearlite.

Another research, also using the JWRIAN software, was conducted by Ma et al. [15] using the same material parameters (U75MnV) as Cai et al. [14], but changing some boundary conditions. The heating condition chosen was the more compatible 
with the experimentally observed heat distribution. The simulation results were shown to be closer to the values extracted by the hole drilling method [16]. Nevertheless, the results of phase transformations showed that, with the simulated cooling rate, there is the possibility of martensite formation, especially in the most extreme region of the rail foot (about $40 \%$ ). Even in the head region, the simulations indicated the presence of approximately $16 \%$ martensite. However, none of these results was validated by any qualitative metallurgical method (metallography).

Porcaro et al. [17] performed simulations by finite element of rail flash-butt welding using Ansys ${ }^{\circledR}$ software without considering the phase transformations other than the pearlite formation. According to the authors, there is no other phase transformation than the eutectoid reaction. As the metallographic contrast from the eutectoid reaction of the HAZ regions where temperatures above Ac1 were reached is easily identified on a polished and etched section, it can be identified as the HAZ edge of a welded rail.

The simulation performed by Porcaro et al. [17] assigned different energy densities at the interface between the rails, considering that the differences in heat generated in the head, web, and foot, according to the paper by Mansouri and Monshi [18], which mentions a higher density of energy in the web region. The results showed that the region of the heataffected zone corresponds to that simulated in the finite element model, having an interface HAZ width with shorter length in the head and foot regions and larger in the rail web region.

This paper's main objective is to study the effect of heat input and cooling rate of a simulated flash-butt weld using the finite element method. The effect of thermal stresses at the heating step before the cooling step was considered, adding the possible reactions in the two steps until the equilibrium state at room temperature. The mechanical strain at the upset stage of the Flash Butt welding was not simulated. This research also analyzed two material parameters dependent on the temperature of rail welding simulation references to investigate their influence on residual stress. In the present study, it has also been proven that even in a flash-butt welded rail with welding parameters compatible with a higher cooling rate, there was no evidence of martensitic formation without the use of forced cooling.

\section{Methodology}

\subsection{Materials and flash-butt welding parameters}

For the microstructural validation of the simulations, rail flash-butt welding was performed. The chemical composition of the rail material is shown in Table 1, and the original microstructure of the rail is shown in Figure 1. The rail can be classified in the Premium class, and its original microstructure is fully pearlitic.

Table 1. Chemical composition of the welded rail.

\begin{tabular}{cccccc}
\hline $\mathbf{C}$ & $\mathbf{M n}$ & $\mathbf{S i}$ & $\mathbf{P}$ & $\mathbf{S}$ & \\
0.79 & 1.01 & 0.22 & 0.02 & 0.01 & 0.24 \\
\hline
\end{tabular}

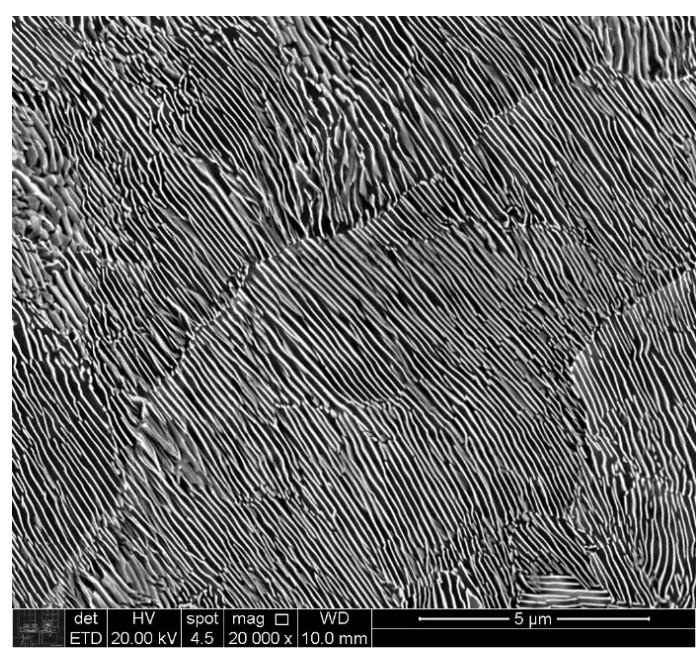

Figure 1. Rail original microstructure - fully pearlitic microstructure. SEM, $2 \%$ Nital solution immersion for $30 \mathrm{~s}$ etching.

The welding parameters used are described in Table 2, and these parameters were chosen because they represent the welding with smaller HAZ width (approximately $30 \mathrm{~mm}$ ) [6,7]. This narrow HAZ width tends to have a higher cooling rate, and as this weld had a smaller HAZ width, the cooling rate was also higher. Thus, if there is a chance of a martensitic transformation (or any acicular microconstituents) these parameters had a higher chance. Also, this set of welding parameters has presented a better mechanical property for the welded joint $[6,7,19]$. As this weld represents a HAZ size similar to one from the simulations and had a higher cooling rate, these parameters were chosen in order to validate the microstructure (and the eventual presence of acicular microconstituents). 
Table 2. Rail flash-butt welding parameters.

\begin{tabular}{cc}
\hline Parameter & Value \\
Pulse current & $60 \mathrm{kA}$ \\
Number of pulses & 8 \\
Upset force & $550 \mathrm{kN}$ \\
\hline
\end{tabular}

Samples for metallographic analysis of the welded rail were taken from the central region of the web and at the edge of the rail foot. The samples were sanded to \#2000 and polished following the sequence of $6 \mathrm{~mm}, 3 \mathrm{~mm}$, and $1 \mathrm{~mm}$. The etching was carried out by immersion in a $1 \%$ Nital solution for $30 \mathrm{~s}$ at room temperature.

The microstructure was observed through scanning electron microscopy (SEM) due to the refined microconstituents were not clear enough by optical microscopy. The regions of interest were the central area of the weld, a section almost interfaced with the spheroidization region (the zone that reached temperatures between $900^{\circ} \mathrm{C}$ and $850{ }^{\circ} \mathrm{C}$ ), and the region of maximum spheroidization, which according to Nishikawa and Goldenstein [20] is the region of equilibrium of three phases that reached approximately $735^{\circ} \mathrm{C}$.

\subsection{Finite element simulation}

The simulation by the finite element method was performed using Abaqus 6.13 software ${ }^{\circledR}$. An analysis was done with a non-linear thermal transient module from a 3D elastoplastic model. A rail profile was created with the dimensions according to AREMA (Figure 4-1-5.136RE from Chapter 4 section 1.1 [21]). The total length of the model was extruded as four times the total rail height to obtain a semi-infinite length and not affect the thermal analysis. The solid rail model (Figure 2) was generated with a mesh with 55430 elements and 63168 nodes. The mesh size close to the heat source (rail face) was smaller than the mesh size far from this region in order to improve the model results in the weld region while preventing long simulation times. The mesh was composed of an 8-node thermally coupled solid with a trilinear displacement and temperature feature.

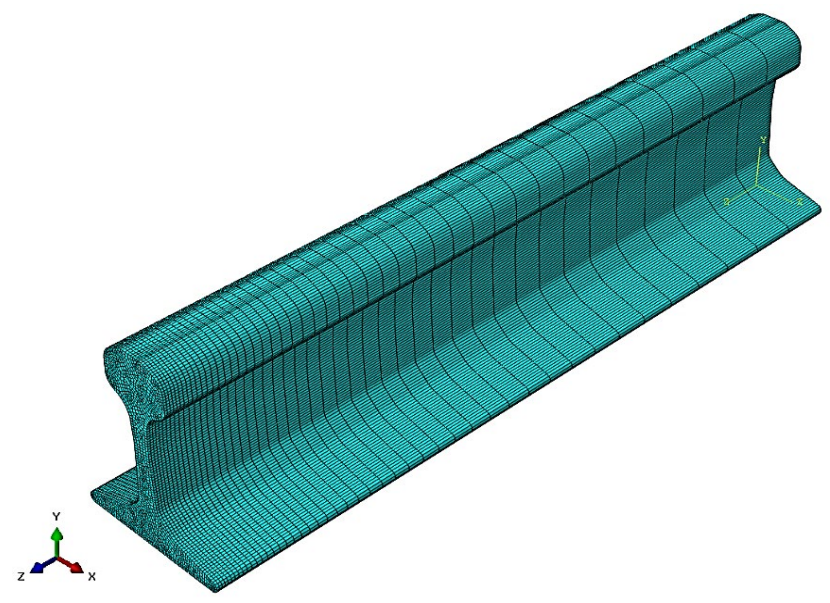

Figure 2. Rail model with the meshing distribution. The heat source was applied at the transversal surface at the left corner (with the most refined meshes).

The flash-butt welding simulation consisted of two steps, a heating step and the cooling processes. Although the upset force would be an excellent boundary condition to consider on residual stresses, it was not considered in these first simulations. This parameter will be studied in future work. The heating condition consisted of applying thermal energy at the rail face over a defined time, without convective cooling at the surfaces. The cooling process consisted of stopping the heating source and the start of convective cooling localized only at the rail surface (excluding the extreme faces).

For the heating parameters selection, several simulations were performed with only the heating step until reaching the maximum temperature and HAZ length:

- According to temperature field evolution simulations, the maximum temperature of a flash-butt weld reached $1355^{\circ} \mathrm{C}$ [9].

- The spheroidized pearlite microstructure can signalize the visible HAZ microstructural alteration; it results from a divorced eutectoid reaction that occurs during cooling a region that barely reached the eutectoid transformation temperature $\mathrm{AC}_{1}[20]$. Therefore, the HAZ size was calculated by the length of the face until reaching $727^{\circ} \mathrm{C}$ after the heating process.

Several simulations were performed modifying the heat source magnitude and simulation time for three HAZ size parameters: $24 \mathrm{~mm}, 30 \mathrm{~mm}$, and $54 \mathrm{~mm}$ (as these values are similar to the welding observed in previous research [6,7]); along with the maximum temperature of $1355^{\circ} \mathrm{C}$. 
After the heating step, the cooling step was performed, adding the residual stresses generated by the previous step. This step consisted of a surface film module, consisting of a convective cooling from the simulation software, and a heat transfer coefficient $(h)$ varying in three magnitudes $\left(30 \mathrm{~W} / \mathrm{m}^{2} \mathrm{~K}, 50 \mathrm{~W} / \mathrm{m}^{2} \mathrm{~K}\right.$, and $\left.80 \mathrm{~W} / \mathrm{m}^{2} \mathrm{~K}\right)$. As this parameter is directly correlated with the cooling rate, a variation of this parameter was used as a forced cooling condition, such as forced air cooling after upset. The main objective was to verify how the increase in the convective heat transfer coefficient (i.e., the increase in the cooling rate) allowed the occurrence of martensitic transformation. The $h$ is obtained from Equation 1, which describes the convection heat loss as a function of the temperature difference.

$\dot{Q}=h \cdot A\left(T_{2}-T_{1}\right)$

In which $\dot{Q}$ is the heat transfer rate, $A$ is the surface area $\left(\mathrm{m}^{2}\right), T_{2}$ is the room temperature, and $T_{1}$ is the solid temperature.

The general boundary conditions adopted in the simulations are shown in Table 3 . These parameters were constant throughout the simulations.

Table 3. Boundary conditions parameters for the simulation.

\begin{tabular}{|c|c|}
\hline Stefan-Boltzmann constant & $5.67 \cdot 10^{-8} \mathrm{~W} /\left(\mathrm{m}^{2} \mathrm{~K}^{4}\right)$ \\
\hline Density & $7860 \mathrm{~kg} / \mathrm{m}^{3}$ \\
\hline Room temperature & $25^{\circ} \mathrm{C}$ \\
\hline Cooling step time & Until mean global temperature reaches $25^{\circ} \mathrm{C}$ \\
\hline
\end{tabular}

Several studies [17,22-24] considered the temperature annealing effect in simulations. According to the authors, the annealing temperature $\left(T_{\alpha}\right)$ can be considered the minimal temperature above which the material loses its hardening memory. The residual stresses from the element history are only effective below $T_{\alpha}$. Some authors [22,25] affirmed that the annealing effect temperature for rail steels can be considered to be $650{ }^{\circ} \mathrm{C}$. Thus, the present model considered the effect of the annealing temperature $\left(T_{\alpha}\right)$ of $650^{\circ} \mathrm{C}$.

The first simulation set was performed using material parameters and mechanical properties of the material as a function of temperature extracted from Cai et al. [14] and Ma et al. [15] papers. The second simulation set was performed with the material's parameters and mechanical properties as a function of temperature, extracted from the paper by Tawfik et al. [22]. All temperature-dependent material parameters of the two simulation sets are described in Figure 3.

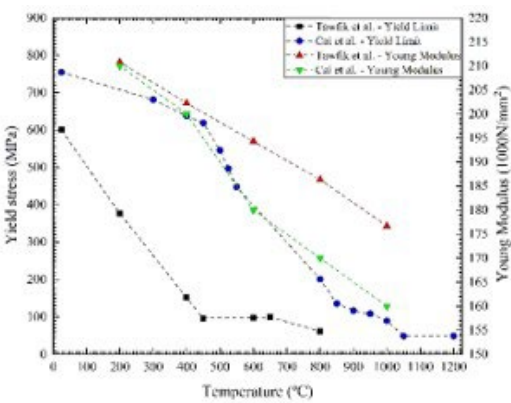

(a)

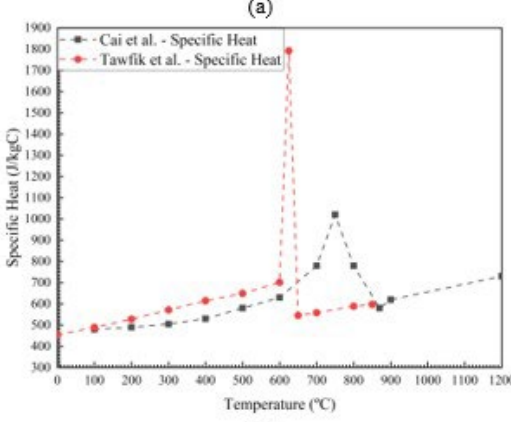

(c)

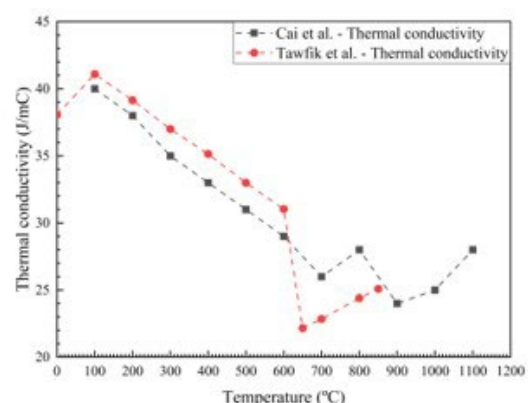

(b)

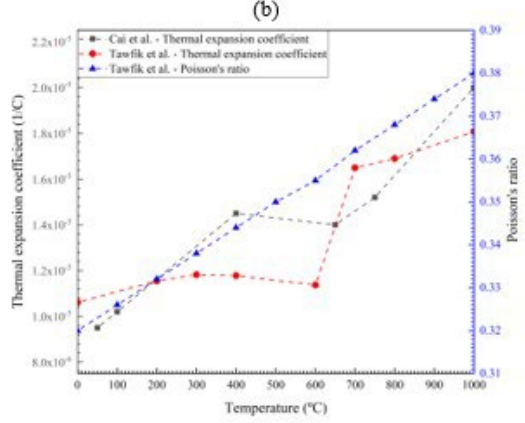

(d)

Figure 3. Material's parameters according to Cai et al. and Ma et al. [14,15], and Tawfik et al. [22].

As experimental results from several authors $[6,7,26,27]$ showed neither bainitic nor martensitic transformation products, it was considered that only the pearlitic transformation occurred. 


\section{Results and discussion}

\subsection{First simulation set}

After a series of simulations, a total of three heat sources were chosen. A plot of the exponential regression of all the heat distribution simulated presented an $\mathrm{R}^{2}$ above 0.99 for the HAZ size calculation. The simulation's maximum temperature mean was $1355^{\circ} \mathrm{C}$, very close to that simulated and observed by Weingrill et al. [9].

In order to simplify the identification of parameters for this research, the nomenclature of the three different heat inputs was established: E1, E2, and E3; in which E1 represents the lower heat input (and lower HAZ size of 24 mm), E2 represents a medium heat input (with an intermediate HAZ size of $30 \mathrm{~mm}$ ), and E3 represents the higher heat input (and higher HAZ size of $54 \mathrm{~mm}$ ). All of these HAZ sizes are in accordance with experimental results of Alves et al. [6] and Bauri et al. [7]. Figure 4 shows the distribution of thermal stresses after the heating process using the Ma et al. [15] and Cai et al. [14] material parameters.

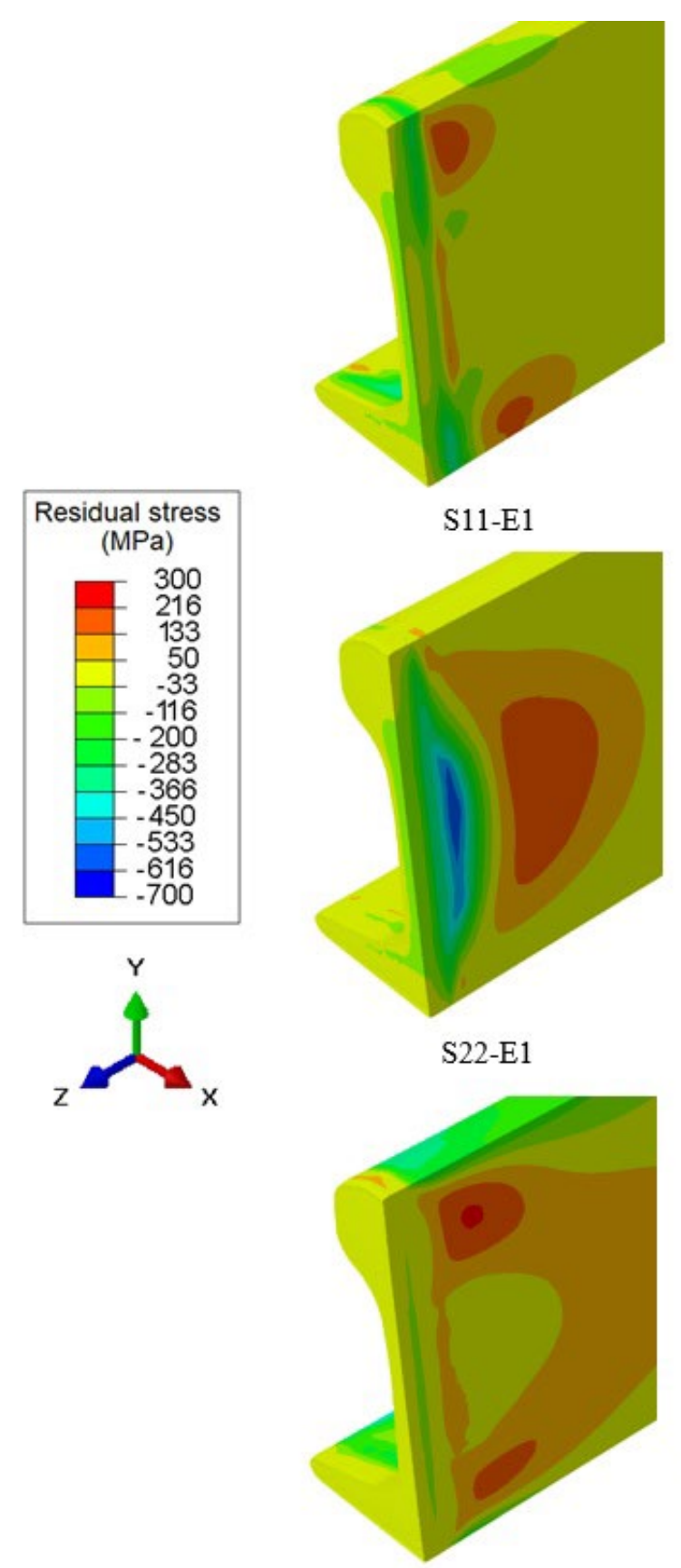

S33-E1

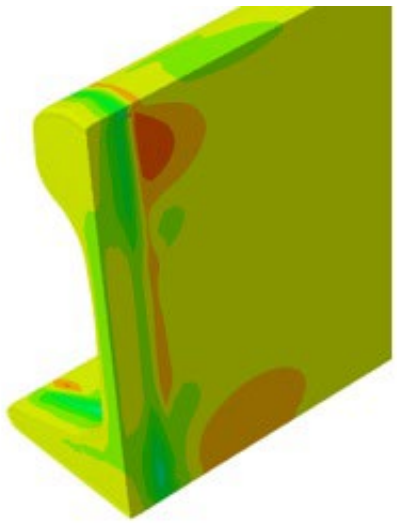

S11-E2

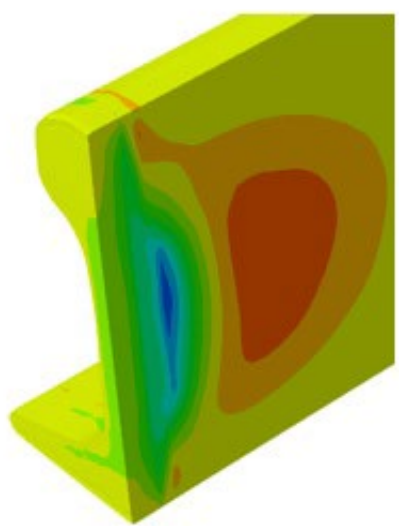

S22-E2

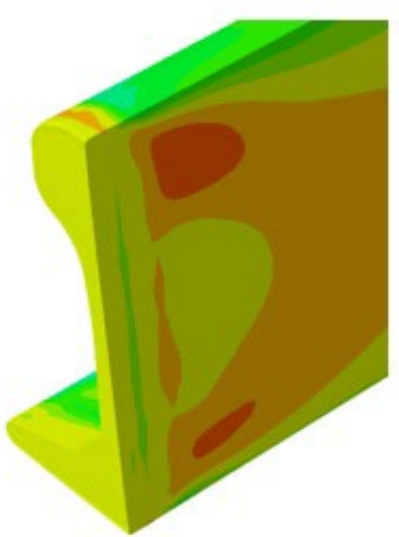

S33-E2

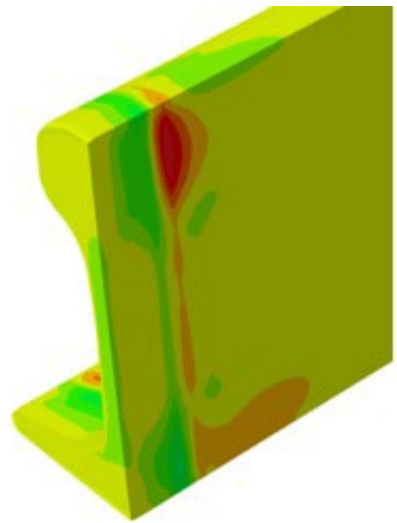

S11-E3

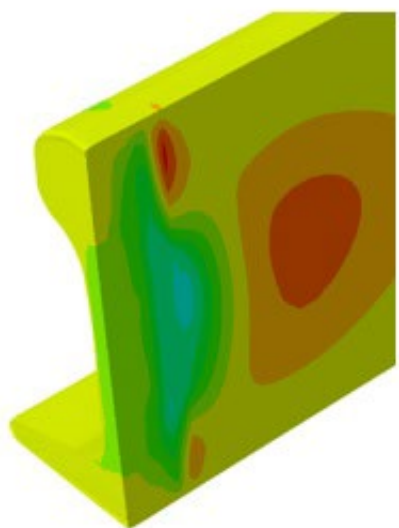

S22-E3

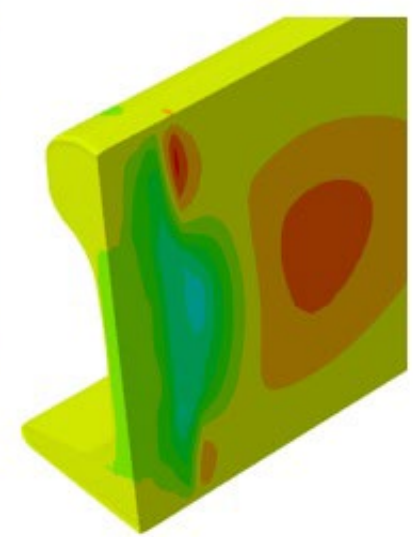

S33-E3

Figure 4. Thermal stress distribution after the heating process of the first simulation set. S11, S22, and S33 represent the residual stresses along the $x$, $y$, and $z$ directions, respectively. E1, E2, and E3 represent the welding heating parameters to achieve a HAZ size of $24 \mathrm{~mm}, 30 \mathrm{~mm}$, and $54 \mathrm{~mm}$, respectively. 
As the model adopted an amount of heat inserted in the fixed face, the amount of heat observed in the web region was slightly higher than the head. Mansouri and Monshi [18] showed that the heat generated (current density) by the flash-butt rail welding process is greater in the web region than in the foot and head regions. This feature generates a heat-affected zone with a non-straight interface and larger in the web region. This effect of greater relative energy in the web region in relation to the head and foot regions was also very well documented, and the data are in accordance with Porcaro et al. [17].

In general, the heating process, which occurs in a non-uniform way along the length of the rail, generates several tensile and compression thermal stresses. The thermal stresses generated at the heating step in the three main directions are shown in Figure 4. S11, S22, and S33 represent the stress components in the $x, y$, and $z$ directions.

Due to the annealing temperature, in Figure 4, the most heated part close to the surface presented thermal stresses of almost no magnitude. Thus, as explained previously, the hardness memory is reset, and the thermal stress is recorded again afterward. This effect can be better visualized during the observation of the welding process as a function of time to evaluate the influence of the welding heating parameters on the thermal and residual stresses.

Notably, thermal compression stresses are usually followed by tensile thermal stress except the S33, which shows compression residual stress in the corners of the rail head and at the rail foot edge.

The simulations results with different cooling rates, counting the vertical residual stresses ( $y$-direction - S22) accumulated by the heating process, are described in Figure 5 . It is noted that there is not much difference between the figures, indicating that the cooling process did not influence the distribution of heat on residual stresses qualitatively.

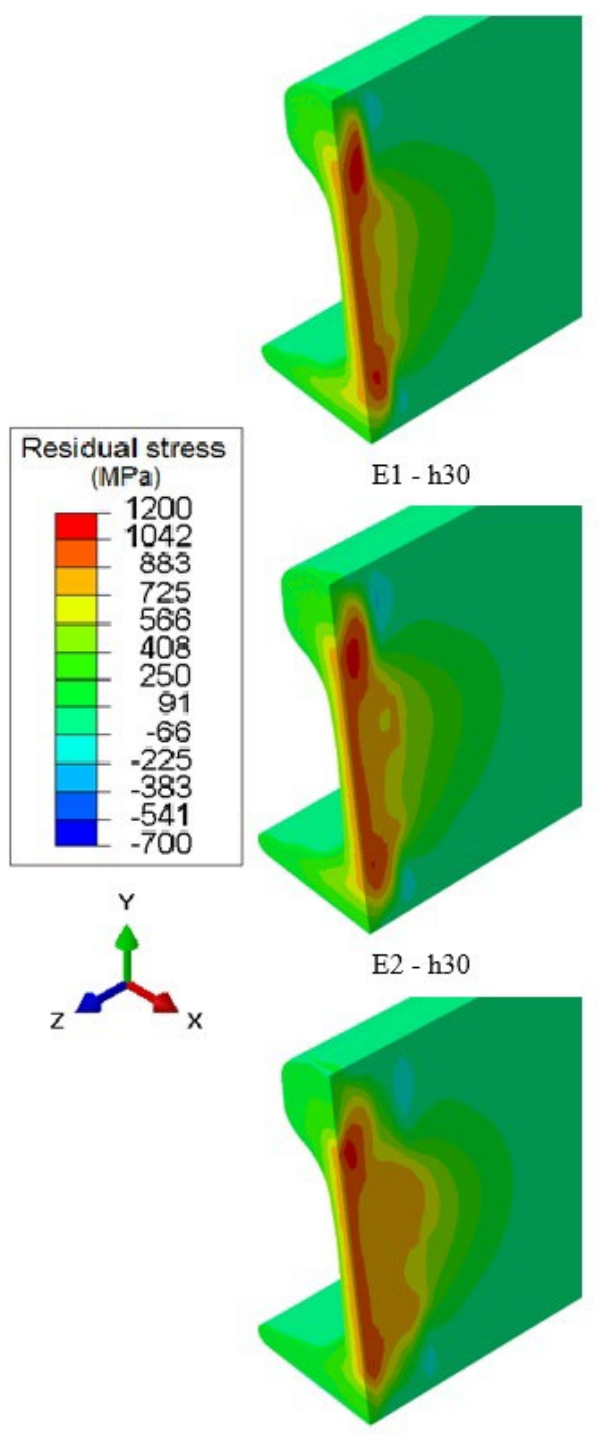

E3 - h30

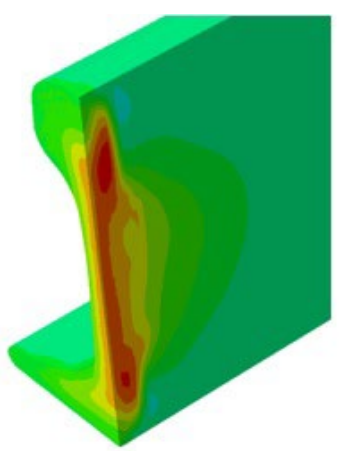

E1 - h50

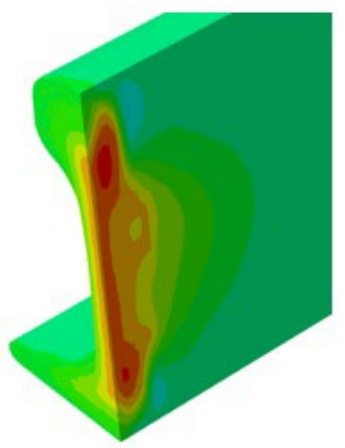

E2 - h50

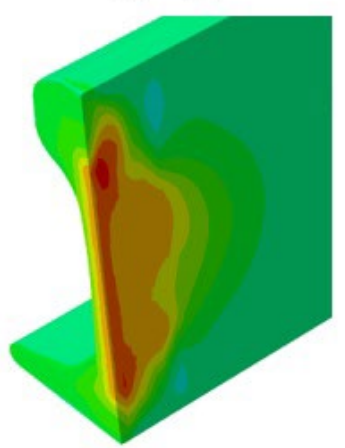

E3 - h50

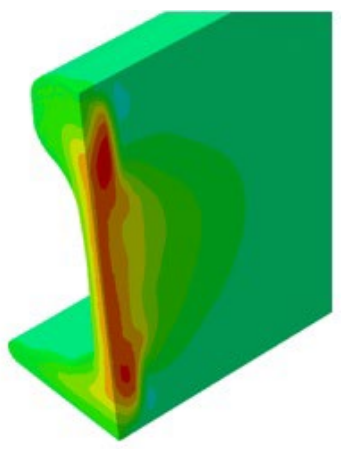

E1- h80

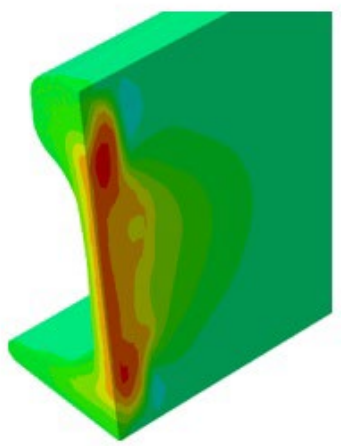

E2 - h80

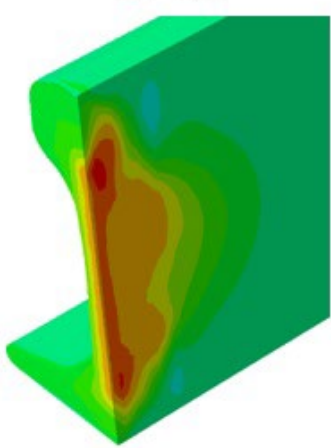

E3 - h80

Figure 5. S22 residual stress distribution after different cooling rates of the first simulation set. E1, E2, and E3 represent the welding heating parameters to achieve a HAZ size of $24 \mathrm{~mm}, 30 \mathrm{~mm}$, and $54 \mathrm{~mm}$, respectively. The h30, h50, and h80 designations represent the heat transfer coefficient varying from $30 \mathrm{~W} / \mathrm{m}^{2} \mathrm{~K}, 50 \mathrm{~W} / \mathrm{m}^{2} \mathrm{~K}$, to $80 \mathrm{~W} / \mathrm{m}^{2} \mathrm{~K}$, respectively. 
The results also show tensile stresses in the rail web. This high intensity of tensile stress is beyond the yield limit, leading to a plastic deformation. These values must change when considering the upset force, characteristics of the flash-butt welding process.

It is interesting to remember that this direction of residual stresses can generate and/or facilitate the appearance of horizontal fatigue in the rail web, as shown by Godefroid et al. [3] and Ito and Gomes [5].

Residual stresses in the longitudinal direction (z-direction - S33) as a function of cooling rates and counting the stresses accumulated by the heating process are shown in Figure 6.

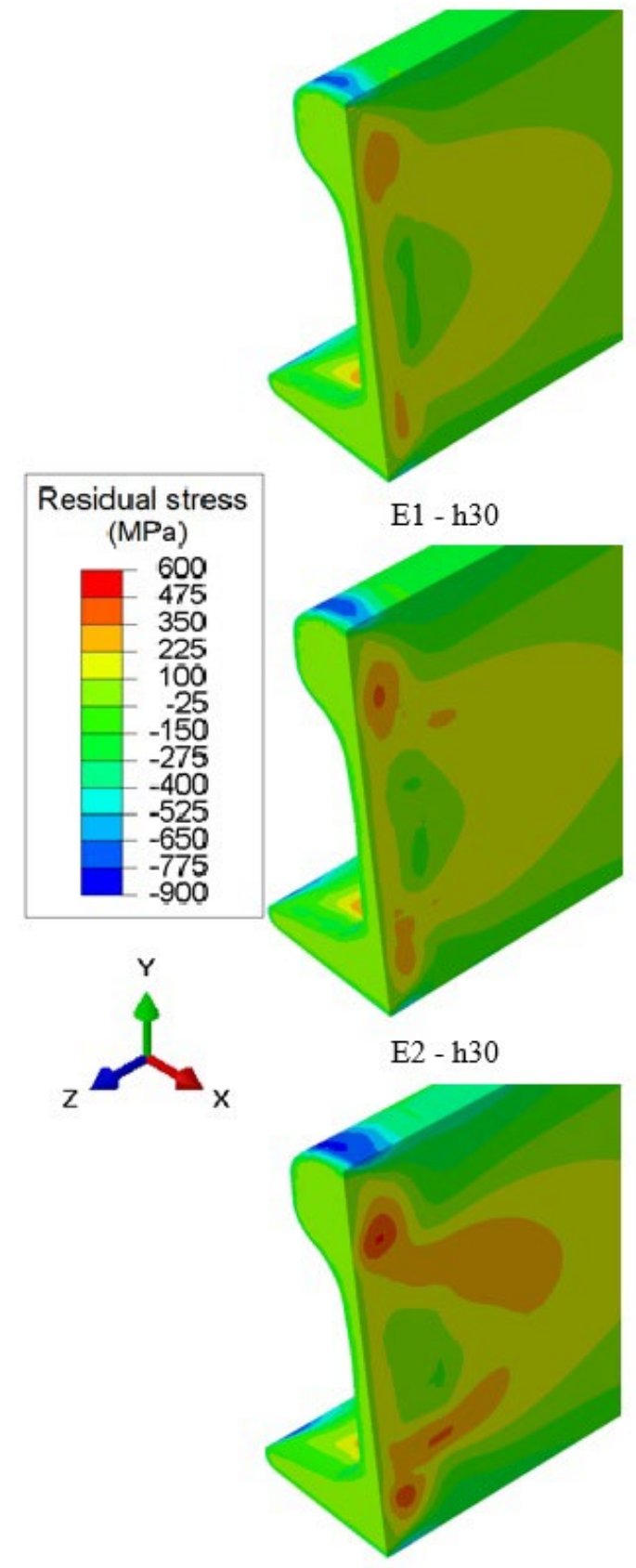

E3 - h30

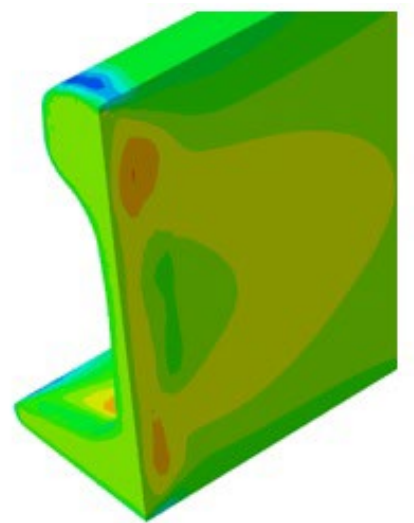

$\mathrm{E} 1-\mathrm{h} 50$

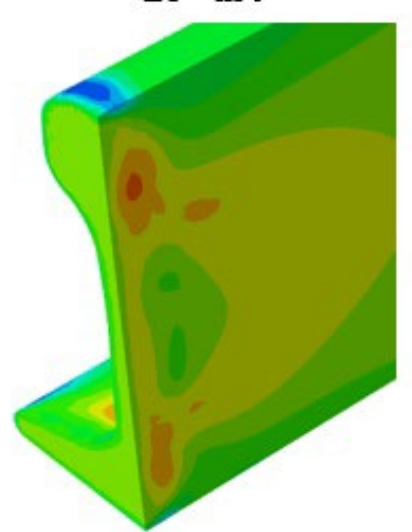

$\mathrm{E} 2-\mathrm{h} 50$

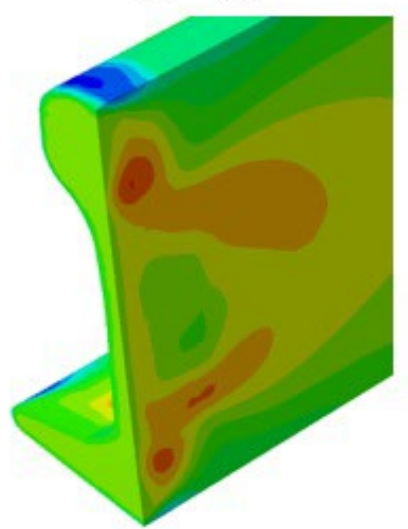

$\mathrm{E} 3-\mathrm{h} 50$

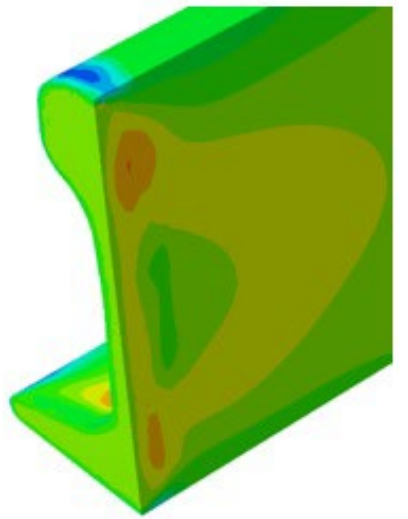

E1 - h80

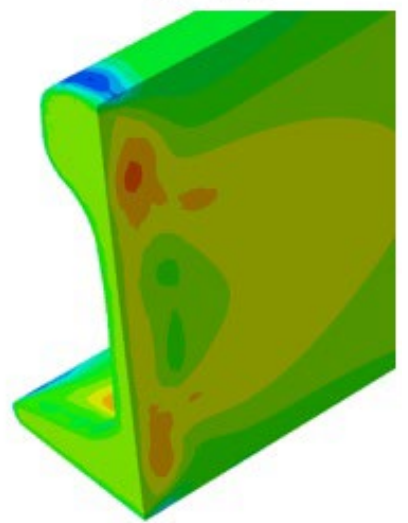

E2 - h80

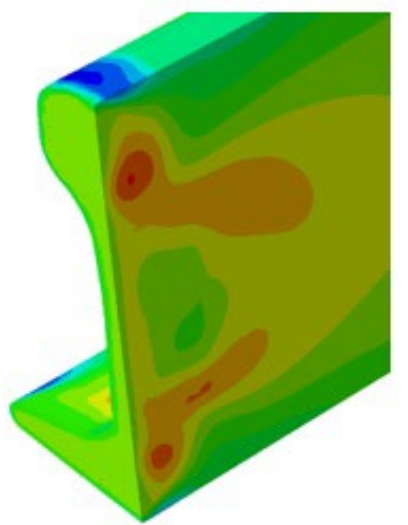

E3 - h80

Figure 6. S33 residual stress distribution after different cooling rates of the first simulation set. E1, E2, and E3 represent the welding heating parameters to achieve a HAZ size of $24 \mathrm{~mm}, 30 \mathrm{~mm}$, and $54 \mathrm{~mm}$, respectively. The h30, h50, and h80 designations represent the heat transfer coefficient varying from $30 \mathrm{~W} / \mathrm{m}^{2} \mathrm{~K}, 50 \mathrm{~W} / \mathrm{m}^{2} \mathrm{~K}$, to $80 \mathrm{~W} / \mathrm{m}^{2} \mathrm{~K}$, respectively.

Again, there is no qualitative difference between cooling rates. Nevertheless, it is possible to see a significant difference between the welding energies (and their consequent HAZ sizes). 
Another feature is the compression stress at the superficial rail head. It is worth remembering that this direction of residual stresses can influence the fatigue resistance of rolling contact.

In order to observe the residual stresses more quantitatively, the values of residual stresses in the longitudinal direction were plotted starting from the heated face. Both the vertical residual stress values (S22) were plotted in the center of the rail web, and the horizontal residual stress values (S33) at the rail head top. Both results are shown in Figure 7.

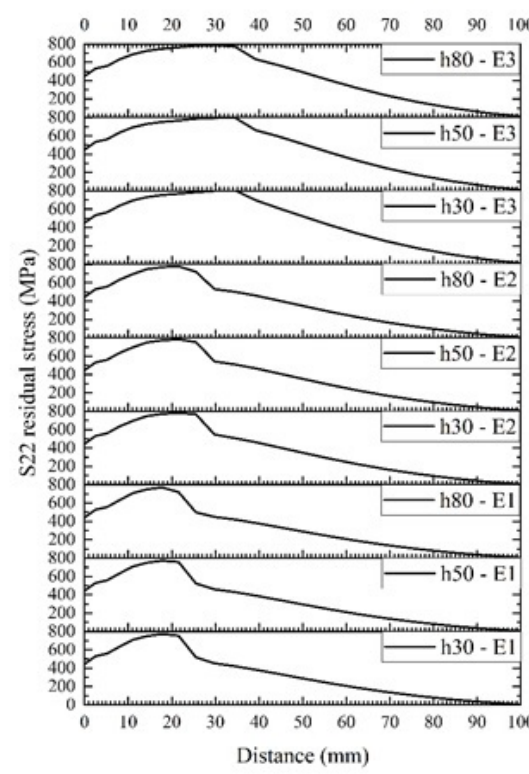

(a)

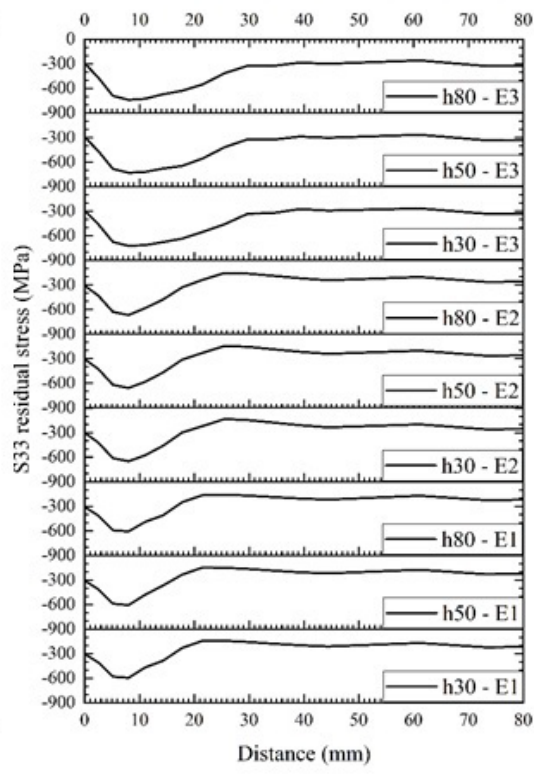

(b)

Figure 7. Residual stress in relation to the heated surface distance of the first simulation set. (a) S22 vertical at the rail web center and (b) S33 longitudina at the rail head top. E1, E2, and E3 represent the welding heating parameters in order to achieve a HAZ size of $24 \mathrm{~mm}, 30 \mathrm{~mm}$, and $54 \mathrm{~mm}$, respectively. The $h 30, h 50$, and h80 designations represent the heat transfer coefficient varying from $30 \mathrm{~W} / \mathrm{m}^{2} \mathrm{~K}, 50 \mathrm{~W} / \mathrm{m}^{2} \mathrm{~K}$, to $80 \mathrm{~W} / \mathrm{m}^{2} \mathrm{~K}$, respectively.

Multiple regressions were performed to determine the influence of the simulation parameters on the maximum tensile stress and minimum compression stress from Figures 5 and 6.

The result of multiple regression of the $S 22$ axis maximum tensile stress value is described in Equation 2 . The $R^{2}$ of the regression was 0.9968 , and the $p$-value of the regression was less than 0.001 , meaning that the parameters describe the result variable.

$$
S 22_{\max }=1217.97-6.421 \cdot H A Z+0.718 \cdot h+0.0892 \cdot H A Z^{2}-0.00356 \cdot h^{2}
$$

In which $H A Z$ is its width, in $\mathrm{mm}$, and $h$ is the heat transfer coefficient, in $\mathrm{W} /\left(\mathrm{m}^{2} \mathrm{~K}\right)$.

These results showed that both the HAZ width and the heat transfer coefficient were related to the maximum stress value S22. However, the higher the cooling rate, represented by a high heat transfer coefficient, the lower the maximum tensile stress at the center of the weld. These values are surprising and future confirmation of residual stresses with, and without cooling will be carried out to validate these results.

The result of multiple regression of the $\mathrm{S} 33$ axis minimum tensile stress value is described in Equation 3 . The $\mathrm{R}^{2}$ of the regression was 0.9991 , and the $p$-value of the regression was less than 0.001, meaning that the parameters describe the result variable.

$$
S 33_{\min }=-735.84-3.575 \cdot H A Z-0.3678 \cdot h+0.03417 \cdot H A Z^{2}+0.001889 \cdot h^{2}
$$

In this case, the HAZ width had much more influence on the minimum residual stress in the longitudinal direction. It is interesting that the HAZ width and the heat transfer coefficient do not interact $(H A Z \cdot h)$. However, in general, the larger the HAZ size, and the greater the $h$, the lower the horizontal residual stress at the rail head top.

A representative form of Equations 2 and 3 can be seen in the graphs of Figures 8-a and 8-b. Figure 8-a shows the distribution of maximum vertical residual stress and Figure 8-b shows the distribution of minimum horizontal residual stress by the HAZ width, and by the heat transfer coefficient $(h)$. Although studies show a tendency to increase residual stresses as the length of the HAZ decreases [28], it is worth remembering that the data shown in Figure 8 were obtained from the maximum stress S22 and the minimum stress S33. The maximum stress S22 is located inside the rail (in the symmetrical center) at the height of the intersection between the rail web and the rail head. Nevertheless, this tendency discrepancy is an interesting feature and will be studied in future works. 


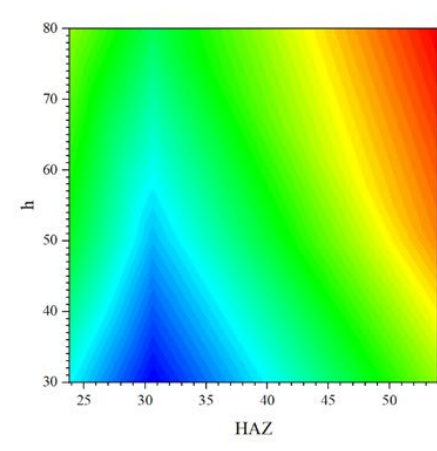

(a)

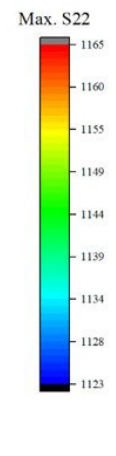

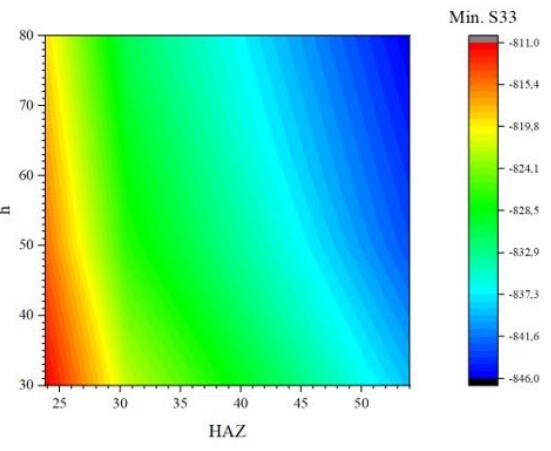

(b)

Figure 8. Residual stress as a function of HAZ width and cooling rate (h) of the first simulation set: (a) Maximum S22 vertical and (b) minimum S33 longitudinal.

\subsection{Second simulation set}

Similar to what was done with the properties obtained from the papers by Ma et al. [15] and Cai et al. [14], Figure 9 shows the distribution of thermal stresses after the heating process using the Tawfik et al. [22] material parameters. The heating parameters were obtained by comparing both the maximum temperature and HAZ width similar to the previous simulations.

The evolution of the stresses according to the amount of welding energy is noteworthy. For stresses in the $\mathrm{x}$-direction (S11) the greatest extent and decrease in the magnitude of residual stresses is observed.

In contrast, the magnitude of the tensile stresses in the y-direction increases as the welding energy increases. In addition, the location and distribution of stresses generated by heating occur further away from the heated face.

Thermal stresses in the $z$-direction (S33) have a phenomenon similar to that in the $\mathrm{x}$-direction, in which the magnitude decreases. Still, there is a change in distribution from the heated face from the residual stresses.

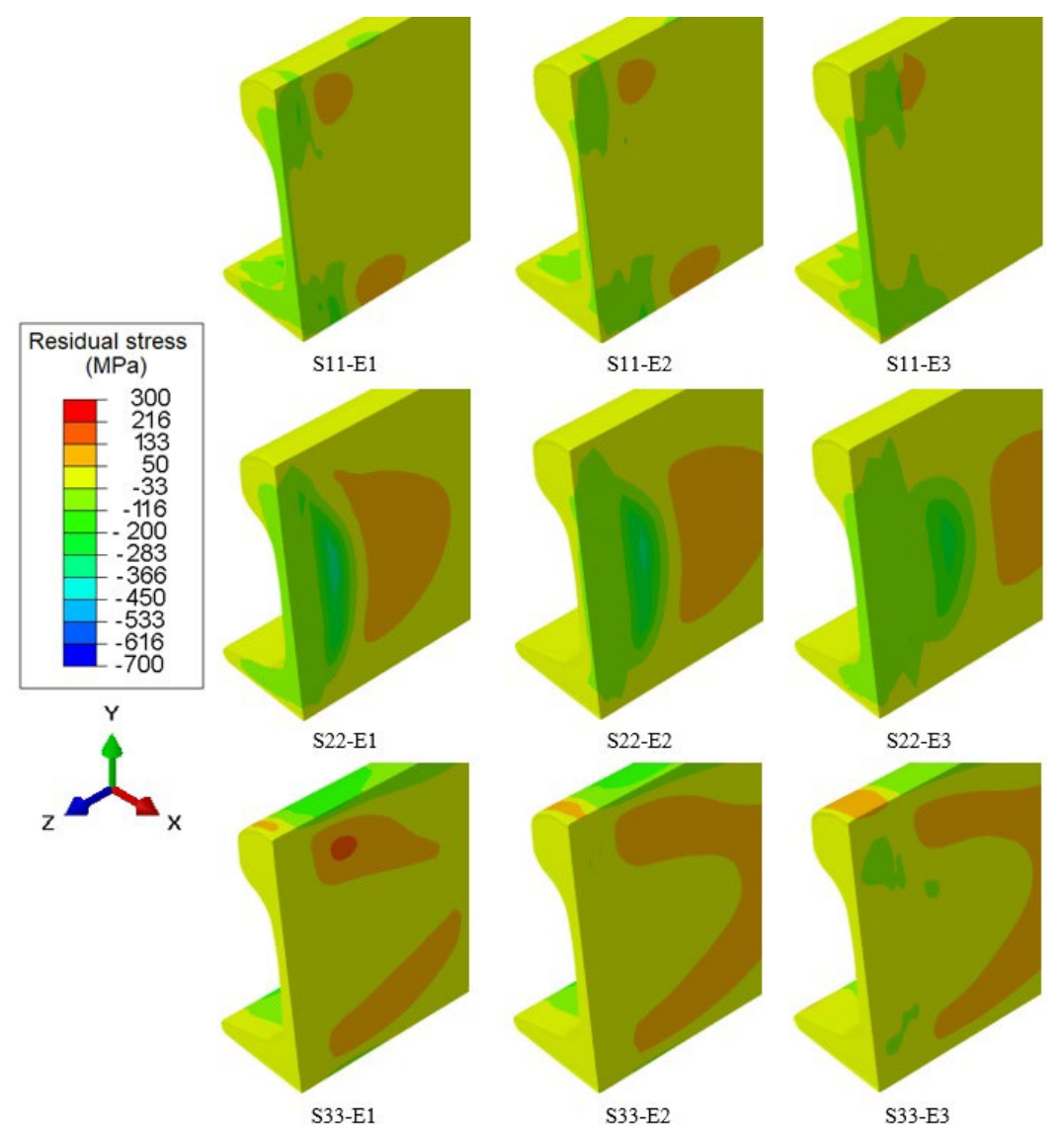

Figure 9. Thermal stress distribution after the heating process of the second simulation set. S11, S22, and S33 represent the residual stresses along the $x, y$, and $z$ directions, respectively. E1, E2, and E3 represent the welding heating parameters in order to achieve a HAZ size of $24 \mathrm{~mm}, 30 \mathrm{~mm}$, and $54 \mathrm{~mm}$, respectively. 
The distribution of vertical residual stresses (y-direction - S22), as a function of welding energy and cooling rate, is shown in Figure 10. Qualitatively, the magnitude of the residual stresses is visible, mainly in the central region of the rail web.

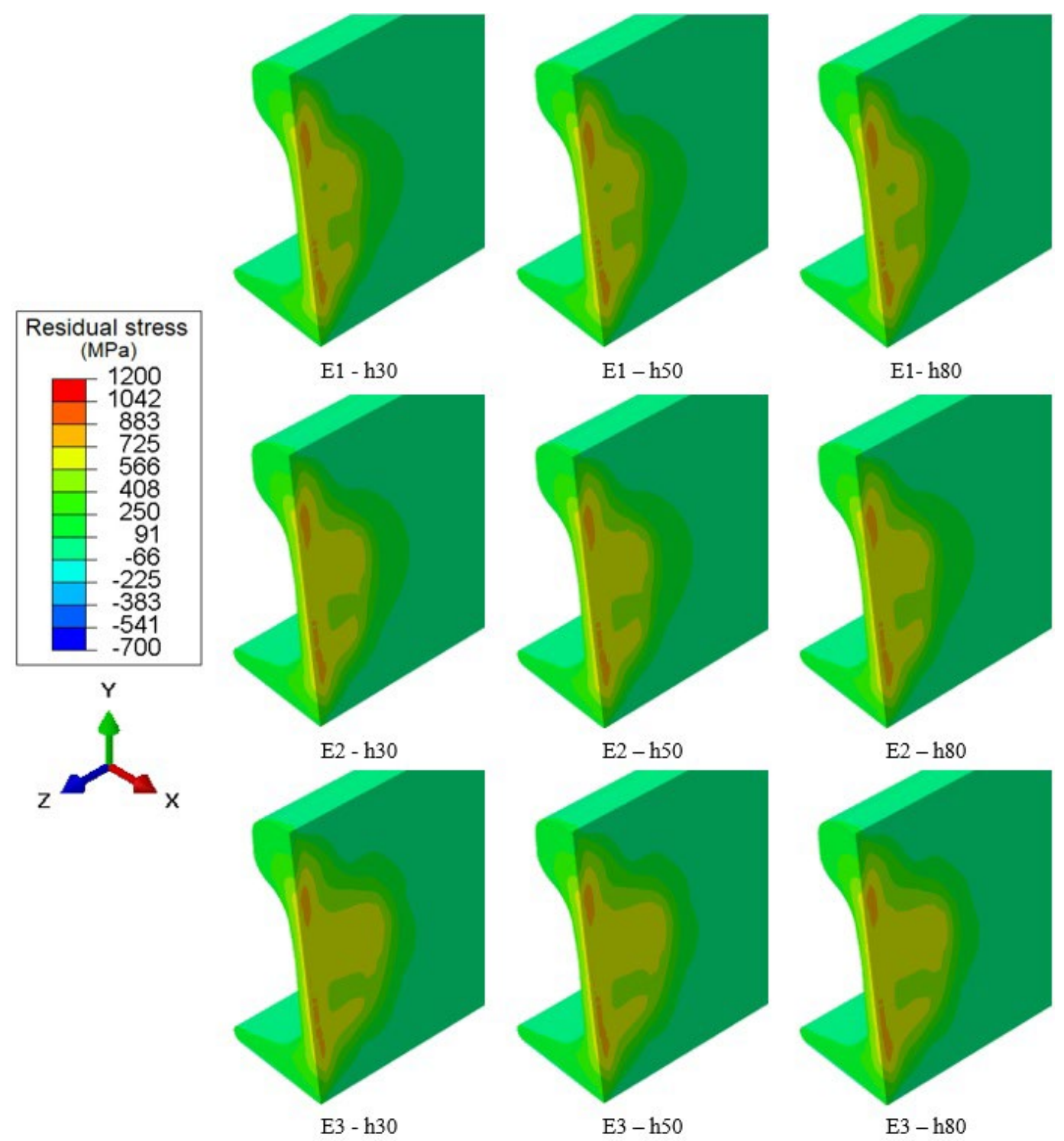

Figure 10. S22 residual stress distribution after different cooling rates of the second simulation set. E1, E2, and E3 represent the welding heating parameters in order to achieve a HAZ size of $24 \mathrm{~mm}, 30 \mathrm{~mm}$, and $54 \mathrm{~mm}$, respectively. The h30, h50, and h80 designations represent the heat transfer coefficient varying from $30 \mathrm{~W} / \mathrm{m}^{2} \mathrm{~K}, 50 \mathrm{~W} / \mathrm{m}^{2} \mathrm{~K}$, to $80 \mathrm{~W} / \mathrm{m}^{2} \mathrm{~K}$, respectively.

A remarkable aspect is the appearance of residual compression stress both in the subsurface region of the E1 rails and in the region after the tensile stress zone and further away from the "welded" face in the E3 rails.

The distribution of residual stresses in the longitudinal direction (z-direction -S33) is shown in Figure 11. Similar to the previous simulations, there was no great qualitative variation between the different simulation parameters. The stresses were concentrated on the surfaces, characterized mainly by residual compression stress in the rail head region.

Although the magnitude cannot be accurately inferred qualitatively, it is noted that the greater the energy input used in the simulation, the greater the region's size with compression stresses at the surface of the rail head.

In contrast, the cooling rate of the E1 and E2 simulations generated a tendency such that the higher the rate, the greater the extent of HAZ. This is not observed in the E3 simulation, revealing an opposite behavior.

The results of the vertical residual stresses on the rail web along the horizontal axis and on the rail head along the distance from the heated face are shown in Figure 12. It is noted that the tensile stress peaks in the rail web (Figure 12a) are not visually influenced by heating energy or cooling rate, but there is an increasing extent with the rise of heating energy. The horizontal residual stress distribution (Figure 12b) showed a propensity for a valley with negative values and the recovery tending to zero, the further the distance from the heated face. 


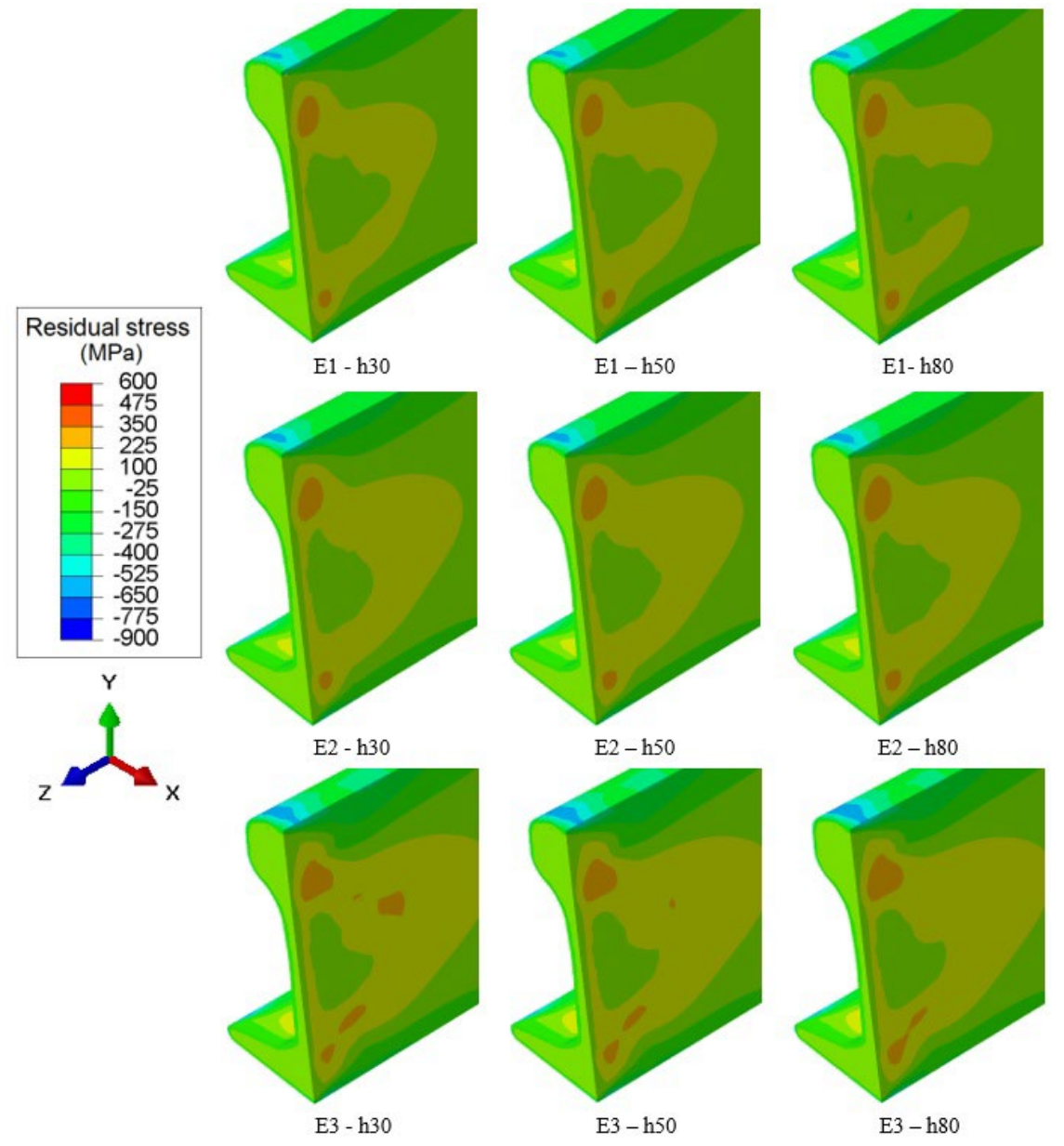

Figure 11. S33 residual stress distribution after different cooling rates of the second simulation set. E1, E2, and E3 represent the welding heating parameters in order to achieve a HAZ size of $24 \mathrm{~mm}, 30 \mathrm{~mm}$, and $54 \mathrm{~mm}$, respectively. The h30, h50, and h80 designations represent the heat transfer coefficient varying from $30 \mathrm{~W} / \mathrm{m}^{2} \mathrm{~K}, 50 \mathrm{~W} / \mathrm{m}^{2} \mathrm{~K}$, to $80 \mathrm{~W} / \mathrm{m}^{2} \mathrm{~K}$, respectively.

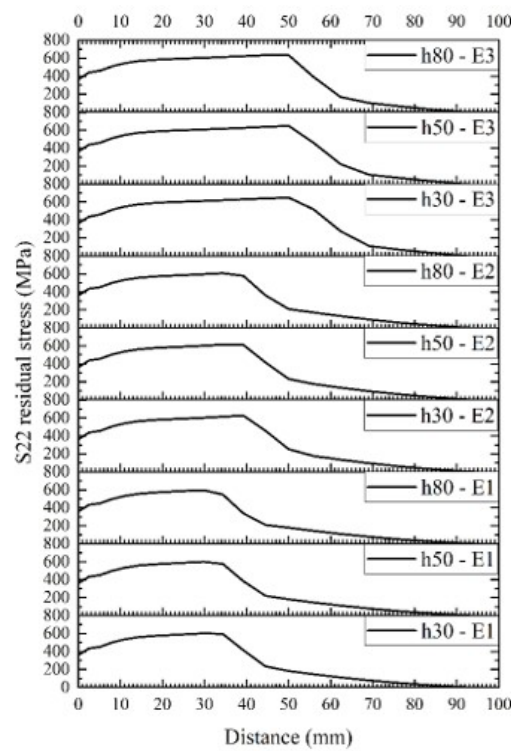

(a)

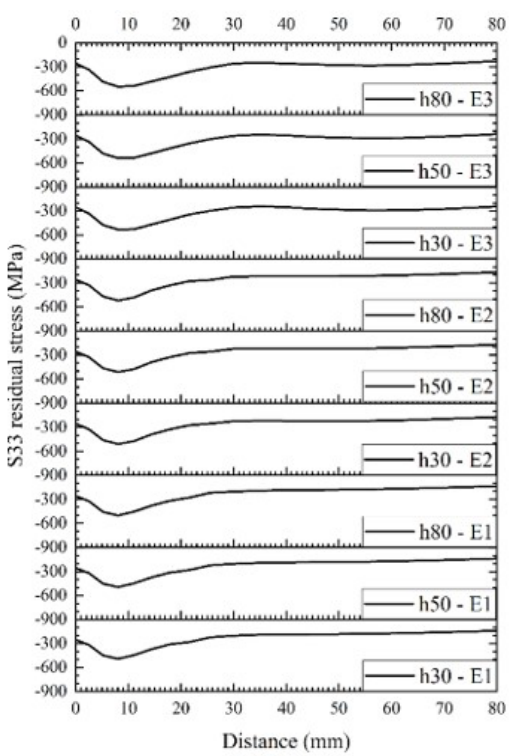

(b)

Figure 12 Residual stress in relation to the heated surface distance of the second simulation set. (a) S22 vertical at the rail web center and (b) S33 longitudinal at the rail head top. E1, E2, and E3 represent the welding heating parameters in order to achieve a HAZ size of $24 \mathrm{~mm}$, $30 \mathrm{~mm}$, and $54 \mathrm{~mm}$, respectively. The h30, h50, and h80 designations represent the heat transfer coefficient varying from $30 \mathrm{~W} / \mathrm{m}^{2} \mathrm{~K}$, $50 \mathrm{~W} / \mathrm{m}^{2} \mathrm{~K}$, to $80 \mathrm{~W} / \mathrm{m}^{2} \mathrm{~K}$, respectively. 
Just as performed in the previous simulation set, multiple regressions were performed to determine the influence of the simulation parameters on the maximum tensile stress and minimum compression stress from Figures 10 and 11 .

The multiple regression results of the maximum tensile stresses as a function of the simulation parameters are represented in Equation 4. The relationship between the result variable and the parameters can be considered as statistically significant, with a $0.018 p$-value, and this regression exhibited an $R^{2}$ fit of 0.88 .

$S 22_{\max }=800.12+0.2205 \cdot H A Z+0.1298 \cdot h$

This regression shows that the maximum top tensile stress is mainly influenced by the cooling rate, contrary to the graphs in Figures 11,12 , and 13 . These results probably occurred due to the scale that made the variation difficult to observe visually.

The regression of the minimum horizontal compression stress (Equation 5) showed an $R^{2}$ fit of 0.9814.

$S 33_{\text {min }}=-600.821-0.2034 \cdot H A Z-0.10526 \cdot h$

This result shows that the magnitude of residual compression stress is not significantly affected by the cooling rate, but undergoes great influence from the heating energy.

Graphical visualization of the rail web's tensile residual stresses and the rail head's compression residual stresses are shown in Figure 13. In comparison with Figure 8, we notice a completely different behavior. The distribution of tensile stress peaks was observed in different places when compared to Figure 8a. In contrast, for the compression residual stress field, the maximum stress was found in the field similar to that of Figure $8 \mathrm{~b}$, while the minimum field was found in the opposite region. It is worth noting that the color scale is not the same between Figure 13 and Figure 8, as the results in Figure 13 showed a lower absolute value than the results in Figure 8.

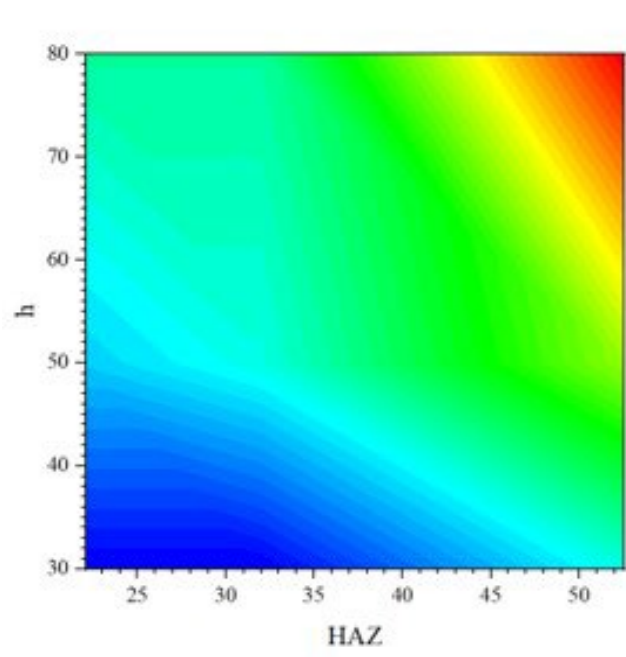

(a)

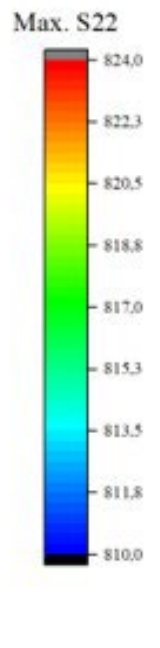

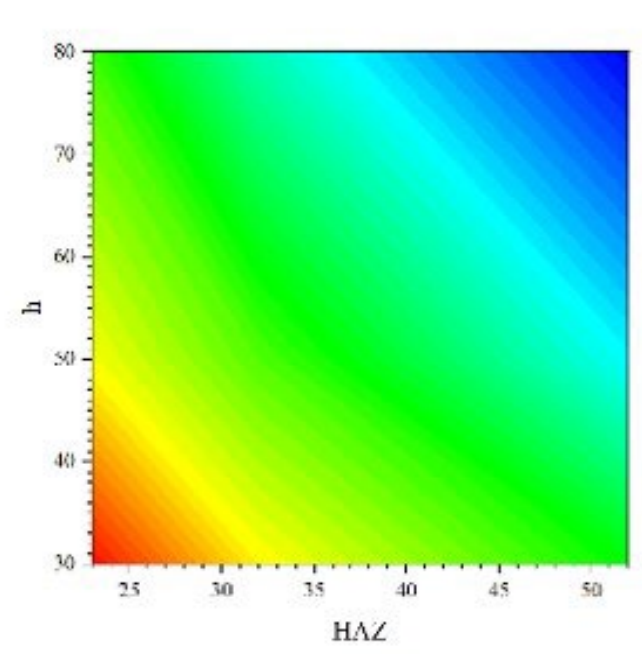

(b)

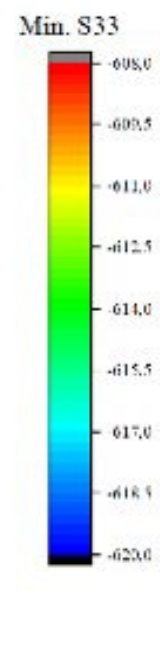

(a) Maximum S22 vertical and (b) minimum S33 longitudinal.

In order to reduce residual stresses (mainly tensile) in the welding process, Tawfik, Mutton and Chiu [22] suggested a heat treatment at the bottom region by high-pressure gas burners for $300 \mathrm{~s}$ after upset. A total of ten flash-butt welds were performed with $6 \mathrm{~V}$ and $7 \mathrm{~V}$ and $300 \mathrm{~kW}$. The simulations were done using Abaqus ${ }^{\circledR}$ Standard software. The parameters used in the simulation were $6 \mathrm{~W} / \mathrm{m}^{2}$ convection, 0.9 radiation emission, Boltzmann constant of $5.67 \cdot 10^{-8} \mathrm{~W} / \mathrm{m}^{2} \mathrm{k}^{4}$, and the heat treatment energy of the burners was considered as $120000 \mathrm{~W} / \mathrm{m}^{2}$. However, the scope of this paper does not involve post-weld heat treating, so this subject will be analyzed in future works.

Comparing the two sets of simulations and comparing the results of measuring residual stresses from other authors [29], it is noted that there is a substantial difference, both in distribution and in magnitude. According to research carried out by Oliveira et al. [29], the horizontal residual stresses in the region of the top of the rail head have a stress characteristic of up to $391 \mathrm{MPa}$ while the vertical residual stress in the rail web had a stress characteristic of approximately $250 \mathrm{MPa}$. These results indicate that many advances must be made in terms of material properties and simulation boundary conditions. Further studies will approach these considerations. 


\subsection{Microstructure validation}

The cooling rate of different regions of the first and second simulations are described in Tables 4 and 5 . It was considered the maximum temperature value (of approximately $1355^{\circ} \mathrm{C}$ ) and a temperature close to $900{ }^{\circ} \mathrm{C}$ to approximately $200^{\circ} \mathrm{C}$. The $200{ }^{\circ} \mathrm{C}$ value was considered as a critical value close to the $\mathrm{Ms}$ (martensite starting temperature) as observed by Porcaro et al. [26]

The cooling rates of the first and the second simulations were very similar (Tables 4 and 5), allowing all statements to be identical for both simulations. For a more didactic visualization, the analyzed region that reached a maximum temperature of $1355^{\circ} \mathrm{C}$ will be indicated as "Face". The region that reached a temperature of approximately $900{ }^{\circ} \mathrm{C}$ will be indicated as "HAZ", in Tables 4 and 5. It was found that the welding energy (also reproduced in the HAZ size) had a considerable effect on the cooling rate.

Table 4. Cooling rate (in ${ }^{\circ} \mathrm{C} / \mathrm{s}$ ) of the region with the highest temperature (of approximately $1355^{\circ} \mathrm{C}$ ) and the region with a temperature close to $900{ }^{\circ} \mathrm{C}$ of the rail head, web, and foot of the first simulation.

\begin{tabular}{|c|c|c|c|c|c|c|c|}
\hline \multirow{2}{*}{$\begin{array}{l}\text { Heat transfer coefficient } \\
\qquad\left[\mathrm{W} /\left(\mathrm{m}^{2} \mathrm{~K}\right)\right]\end{array}$} & \multirow[b]{2}{*}{ Energy parameter } & \multicolumn{2}{|c|}{ Rail head } & \multicolumn{2}{|c|}{ Rail web } & \multicolumn{2}{|c|}{ Rail foot } \\
\hline & & $\begin{array}{c}\text { Face } \\
{\left[{ }^{\circ} \mathrm{C} / \mathrm{s}\right]}\end{array}$ & $\begin{array}{c}\mathrm{HAZ} \\
{\left[{ }^{\circ} \mathrm{C} / \mathrm{s}\right]}\end{array}$ & $\begin{array}{c}\text { Face } \\
{\left[{ }^{\circ} \mathrm{C} / \mathrm{s}\right]}\end{array}$ & $\begin{array}{c}\mathrm{HAZ} \\
{\left[{ }^{\circ} \mathrm{C} / \mathrm{s}\right]}\end{array}$ & $\begin{array}{c}\text { Face } \\
{\left[{ }^{\circ} \mathrm{C} / \mathrm{s}\right]}\end{array}$ & $\begin{array}{c}\mathrm{HAZ} \\
{\left[{ }^{\circ} \mathrm{C} / \mathrm{s}\right]}\end{array}$ \\
\hline \multirow{3}{*}{30} & E1 & 2.27 & 1.37 & 2.37 & 1.42 & 2.68 & 1.60 \\
\hline & E2 & 1.62 & 0.94 & 1.96 & 1.11 & 1.93 & 1.11 \\
\hline & E3 & 0.88 & 0.54 & 1.04 & 0.62 & 1.12 & 0.68 \\
\hline \multirow{3}{*}{50} & E1 & 2.61 & 1.59 & 3.05 & 1.82 & 3.38 & 2.05 \\
\hline & E2 & 1.95 & 1.14 & 2.31 & 1.32 & 2.61 & 1.51 \\
\hline & E3 & 1.28 & 0.77 & 1.48 & 0.88 & 1.63 & 0.98 \\
\hline \multirow{3}{*}{80} & E1 & 3.00 & 2.01 & 3.59 & 2.36 & 3.94 & 2.61 \\
\hline & E2 & 2.67 & 1.54 & 3.10 & 1.77 & 3.43 & 1.97 \\
\hline & E3 & 1.63 & 0.99 & 1.89 & 1.14 & 2.25 & 1.35 \\
\hline
\end{tabular}

Table 5. Cooling rate (in ${ }^{\circ} \mathrm{C} / \mathrm{s}$ ) of the region with the highest temperature (of approximately $1355^{\circ} \mathrm{C}$ ) and the region with a temperature close to $900{ }^{\circ} \mathrm{C}$ of the rail head, web and foot of the second simulation.

\begin{tabular}{|c|c|c|c|c|c|c|c|}
\hline \multirow{2}{*}{$\begin{array}{l}\text { Heat transfer coefficient } \\
\qquad\left[\mathrm{W} /\left(\mathrm{m}^{2} \mathrm{~K}\right)\right]\end{array}$} & \multirow[b]{2}{*}{ Energy parameter } & \multicolumn{2}{|c|}{ Rail head } & \multicolumn{2}{|c|}{ Rail web } & \multicolumn{2}{|c|}{ Rail foot } \\
\hline & & $\begin{array}{c}\text { Face } \\
{\left[{ }^{\circ} \mathrm{C} / \mathrm{s}\right]}\end{array}$ & $\begin{array}{l}\mathrm{HAZ} \\
{\left[{ }^{\circ} \mathrm{C} / \mathrm{s}\right]}\end{array}$ & $\begin{array}{c}\text { Face } \\
{\left[{ }^{\circ} \mathrm{C} / \mathrm{s}\right]}\end{array}$ & $\begin{array}{c}\mathrm{HAZ} \\
{\left[{ }^{\circ} \mathrm{C} / \mathrm{s}\right]}\end{array}$ & $\begin{array}{c}\text { Face } \\
{\left[{ }^{\circ} \mathrm{C} / \mathrm{s}\right]}\end{array}$ & $\begin{array}{c}\mathrm{HAZ} \\
{\left[{ }^{\circ} \mathrm{C} / \mathrm{s}\right]}\end{array}$ \\
\hline & E1 & 2.34 & 1.34 & 2.41 & 1.38 & 2.73 & 1.58 \\
\hline \multirow[t]{3}{*}{30} & E2 & 1.67 & 0.92 & 1.73 & 0.95 & 1.94 & 1.08 \\
\hline & E3 & 0.92 & 0.54 & 1.09 & 0.63 & 1.20 & 0.70 \\
\hline & E1 & 2.69 & 1.55 & 3.18 & 1.81 & 3.67 & 2.11 \\
\hline \multirow[t]{3}{*}{50} & E2 & 1.98 & 1.10 & 2.38 & 1.30 & 2.63 & 1.46 \\
\hline & E3 & 1.23 & 0.72 & 1.43 & 0.83 & 1.55 & 0.91 \\
\hline & E1 & 3.28 & 1.89 & 3.87 & 2.22 & 4.46 & 2.58 \\
\hline \multirow[t]{2}{*}{80} & E2 & 2.59 & 1.43 & 3.02 & 1.66 & 3.40 & 1.89 \\
\hline & E3 & 1.71 & 1.00 & 1.97 & 1.14 & 2.19 & 1.29 \\
\hline
\end{tabular}

To analyze Tables 4 and 5, it is first necessary to compare CCT curves to explore the phase transformations. Two bases of comparison were analyzed, one from the paper with the parameters of the first simulation by Ma et al. [15] and the other previously mentioned by Porcaro et al. [26].

The first CCT diagram (Ma et al. [15]) presented a critical temperature for the martensitic formation (Ms) of approximately $230^{\circ} \mathrm{C}$ between cooling rates of $20^{\circ} \mathrm{C} / \mathrm{s}$ to $10^{\circ} \mathrm{C} / \mathrm{s}$. In addition, the CCT diagram showed traces of martensitic transformation up to a cooling rate of $2{ }^{\circ} \mathrm{C} / \mathrm{s}$. With these critical values, the formation of martensite in the simulations performed with these parameters is expected. 


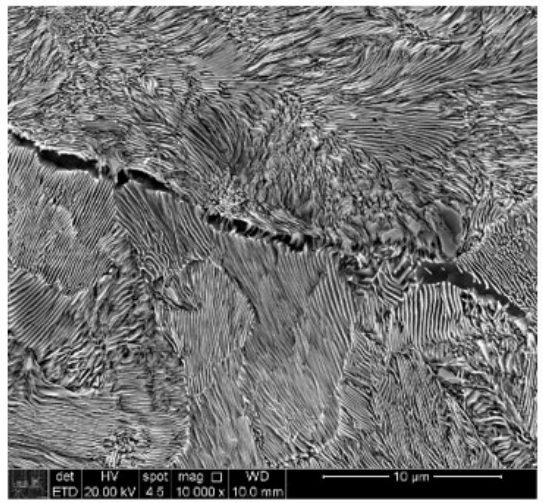

(a)

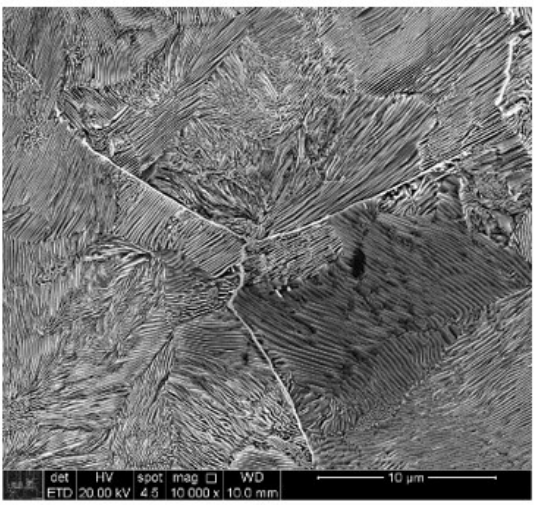

(b)

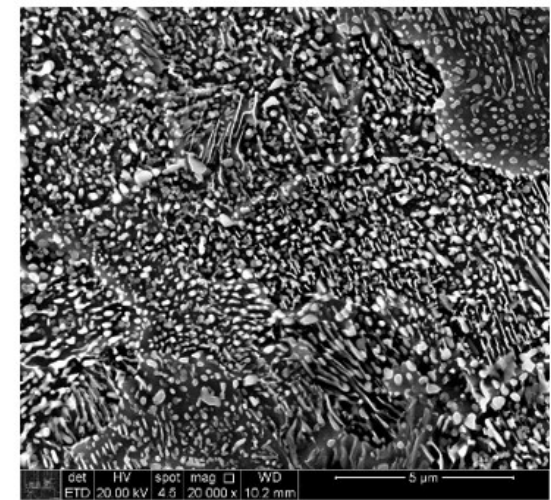

(c)

Figure 14. Microstructure in different regions of flash-butt welding of the rail web: (a) center line; (b) close to $A_{c 3}$ temperature region; and (c) at the inter-critical region with spheroidized microstructure.

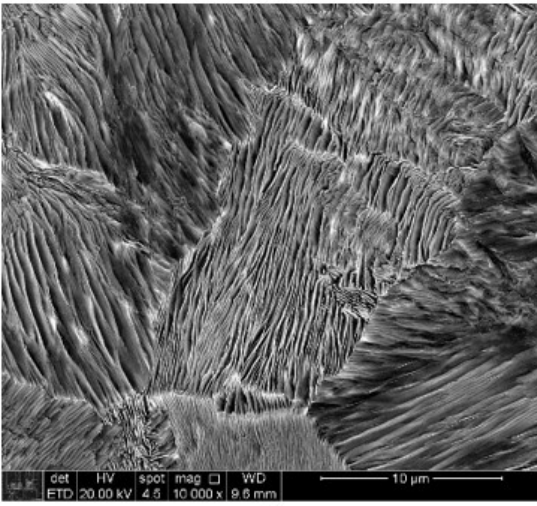

(a)

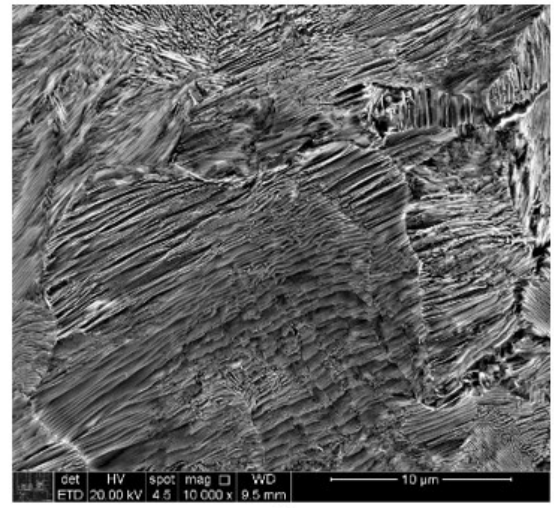

(b)

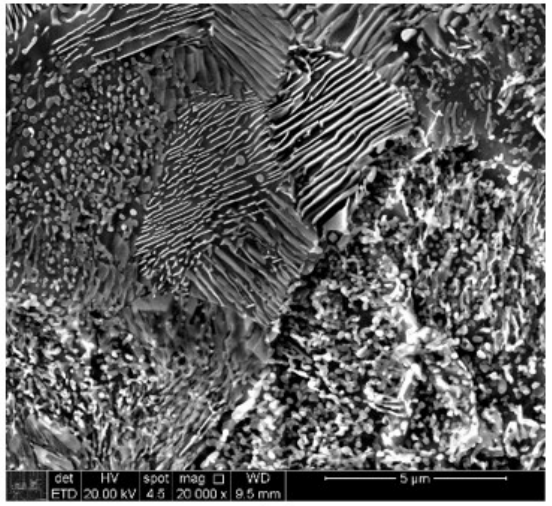

(c)

Figure 15. Microstructure in different regions of flash-butt welding of the rail foot: (a) center line; (b) close to $A_{c 3}$ temperature region; and (c) at the inter-critical region with spheroidized microstructure.

The second CCT diagram (Porcaro et al. [26]) was carried out on railway tracks with two austenitizing temperatures: $1300{ }^{\circ} \mathrm{C}$ and $900^{\circ} \mathrm{C}$. This CCT diagram was a little different from the first diagram. Ms did not vary significantly according to the austenitization temperature, being $(222 \pm 10)^{\circ} \mathrm{C}$ and $(199 \pm 7){ }^{\circ} \mathrm{C}$ for $1300{ }^{\circ} \mathrm{C}$ and $900{ }^{\circ} \mathrm{C}$ full austenitization temperatures, respectively. Another different information point is that there are traces of martensite at a cooling rate of up to $10{ }^{\circ} \mathrm{C} / \mathrm{s}$ for austenitization at $1300^{\circ} \mathrm{C}$ and up to $15^{\circ} \mathrm{C} / \mathrm{s}$ for austenitization at $900{ }^{\circ} \mathrm{C}$.

Through the second CCT diagram with the first simulation set, a great tendency was not shown for martensitic formation in the web and foot region of the rail in any heat transfer coefficient due to relatively high critical rates.

The microstructure of the three different regions of flash-butt welding is shown in Figure 14. The region of the central weld (Figure 14a) is characterized by a region of pro-eutectoid ferrite and pearlitic matrix. This pro-eutectoid ferrite is a characteristic of flash-butt welded rails with a carbon content close to the eutectoid composition that undergoes decarburization during the flashing step of the welding. This singularity is well known, mainly in research related to rail welding by FBW $[6,7,19,20,26,30]$.

The region close to the $A_{c 3}$ temperature (Figure 14b) is characterized by regions with pro-eutectoid cementite that precipitated in an old austenitic grain outline and following pearlitic matrix. Finally, the region of maximum spheroidization (Figure 14c) corresponds to the region with the lower local hardness (of approximately $262 \mathrm{HV}$ ). It is noted that the region corresponds to almost total spheroidization of pearlite by the reaction process of the divorced eutectoid [20].

All of these three regions of the center of the rail web are in accordance with the microstructures observed in the rail head [6,7]. Although the welded rail shown in Figures 14 and 15 is more similar to the condition E2 h30 (see Tables 4 and 5 ), there are no traces of acicular microstructure, especially martensite, along the rail weld. As the martensite would be formed in all simulations with E1 energy, due to the critical cooling rate of the CCT diagram from Ma et al. [19] being very low, simulations with E2 energy would only be possible with a heat transfer coefficient $h$ of $30 \mathrm{~W} /\left(\mathrm{m}^{2} \mathrm{~K}\right)$. The microstructures of Figures 14 and 15 are in agreement even with the CCT diagram from Ma et al. [19]. At the time that the cooling rate is in agreement with that observed in FBW rail welding $[9,20]$, the simulations should not provide fractions of acicular microconstituents.

The microstructures at the end of the rail foot are shown in Figure 15. The central region (Figure 15a) only presents a completely pearlitic microstructure without pro-eutectoid ferrite. The region close to $A_{c 3}$ (Figure 15b) also exhibited a completely 
pearlitic microstructure without the presence of pro-eutectoid cementite. The region of greater spheroidization (Figure 15c) presented islands of pearlitic colonies, therefore less spheroidized microstructure than the same region in the center of the rail web.

As this region (rail foot edge) undergoes the highest cooling rate, ferrite and pro-eutectoid cementite are mitigated by the reaction kinetics [31-33]. Furthermore, the higher cooling rate in the rail web region with the lower presence of pearlite spheroidization suggests that it suppresses the divorced eutectoid reaction. Finally, no acicular microstructure, mainly martensite, was observed along the weld as suggested by other authors $[14,15]$. These results are in agreement with Verhoeven and Gibson [34], which supports that higher cooling rates decrease the tendency for divorced eutectoid transformation.

Martensitic transformation is fundamental in railroad metallurgy for two reasons. The AREMA standard [21] is explicit that there can be no martensite in any rail region. The non-tempered martensite phase provides a heterogeneity of microstructure, mechanical properties, and hardness can be a source of nucleation of fatigue cracks and/or RCF [35-37].

Equations 6 and 7 show a volumetric variation during the decomposition of austenite for the martensitic transformation $\left(\alpha^{\prime}\right)$ and pearlitic transformation ( $p$ ) as a function of the wt.\% of carbon, respectively [38].

$$
\begin{aligned}
& (\Delta V / V)_{\alpha^{\prime}}=4.64-0.53 \% C \\
& (\Delta V / V)_{p}=4.64-2.21 \% C
\end{aligned}
$$

According to these Equations ( 6 and 7 ), if there is a martensitic reaction, and for the material studied here (Table 1 ), with a carbon of $0.79 \%$, a volumetric increase of approximately $4.22 \%$ will occur. In contrast, for the pearlitic transformation, an increase of approximately $2.89 \%$ will occur. These considerations will greatly influence the residual stress distributions [39].

Ma et al. [15] showed that simulations considering phase transformations had a significant difference regarding the distribution of residual stress magnitudes. The martensite formation introduces high alteration due to its expansion during the phase transformation [40]. Nevertheless, the authors stated an increase in the accuracy of residual stresses compared to the experimental data obtained through the hole drilling method [15].

These phase transformations occur at different times and in different locations. The volumetric expansions before the phase transformations will influence the final result. Therefore, great attention must be taken when implementing a phase transformation module, in which it is essential to validate the microstructures found in the different locations of the experimental welds.

\section{Conclusions}

- The use of different material parameters, even when using the same heating and heat extraction conditions, greatly influences the final result of the distribution of residual stresses, mainly in the magnitudes of the residual stresses.

- There is a vertical residual tensile stress concentration in the rail web region, regardless of the material parameters, but with different magnitudes.

- There is a need to obtain parameters of the equivalent material with the new modern rail with Premium and Super Premium quality to obtain more accurate simulations for more modern rail steels.

- The flash-butt welding upset effect was not yet included in the simulation, so introducing this phenomenon could guarantee greater precision for the values of final absolute residual stress.

- The result of the microstructural validation showed that there is no formation of acicular microstructures in the web region and the rail foot, in which there are places known to be regions with a higher cooling rate as confirmed by the simulations.

\section{Acknowledgements}

The authors would like to thank the LTF laboratory and the project "Cátedra de contato entre Roda\&Trilho" of VALE S.A. The authors acknowledge the financial support provided by CAPES (process number: 88887.461594/2019-00).

\section{References}

[1] Schajer GS, Ruud CO. Overview of residual stresses and their measurement. In: Schajer GS. Practical Residual Stress Measurement Methods. Chichester: John Wiley \& Sons, Ltd.; 2013. pp. 1-27. http://dx.doi.org/10.1002/9781118402832.ch1.

[2] Farhangi H, Mousavizadeh SM. Horizontal split-web fractures of flash butt welded rails. In: Prooceedings of 8th International Fracture Conference; 2007 November 7-9; Istanbul. Istanbul: Yildiz Technical University; 2007. p. 509-517.

[3] Godefroid LB, Faria GL, Cândido LC, Viana TG. Fatigue failure of a flash butt welded rail, procedia. Materials Science. 2014;3:1896-1901. http://dx.doi.org/10.1016/j.mspro.2014.06.306. 
[4] Mousavizade M, Farhangi H. Characterization of surface defects associated with flash butt-welded pearlitic rails and their contribution to overload and fatigue failures. Advanced Materials Research. 2010;83-86:1262-1269. http://dx.doi.org/10.4028/www.scientific.net/AMR.83-86.1262.

[5] Ito HL, Gomes JDC. Análise de falhas - um dever do IPT. Revista IPT: Tecnologia e Inovação. 2019;3:35-64.

[6] Alves LHD, Lagares ML, Filho RMM, Tepedino T., Goldenstein, H. Predictive mathematical modeling of the flash-butt welding process to optimize the properties of welds of premium and super premium rails. In: Roney M, Mikalsen H. International Heavy Haul Association. Narvik, Norway: IHHA; 2019. p. 440-447.

[7] Bauri LF, Alves LHD, Pereira HB, Tschiptschin AP, Goldenstein H. The role of welding parameters on the control of the microstructure and mechanical properties of rails welded using FBW. Journal of Materials Research and Technology. 2020;9(4):8058-8073. http://dx.doi.org/10.1016/j.jmrt.2020.05.030.

[8] Saita K, Ueda M, Miyazaki T. Developing technologies to improve the reliability of flash-butt welds. In: International Heavy Haul Association. 11th International Heavy Haul Association Conference; 2017 September 2-6; Cape Town. Red Hook: IHHA; 2017. p. 208215.

[9] Weingrill L, Krutzler J, Enzinger N. Temperature field evolution during flash butt welding of railway rails. Materials Science Forum. 2016;879:2088-2093. http://dx.doi.org/10.4028/www.scientific.net/MSF.879.2088.

[10] Haibatollahi SP, Tehrani PH. Prediction of residual stress distribution in flash butt welded rails using electro-thermo-mechanical simulation. International Journal of Vehicle Structures and Systems. 2013;5(1):53-57. http://dx.doi.org/10.4273/ijvss.5.2.02.

[11] KuhIman C, Sehitoglu H, Gallagher M. The significance of material properties on stresses developed during quenching of railroad wheels. In: American Society of Mechanical Engineers/Institute of Electrical and Electronics Engineers. Joint ASME/IEEE Railroad Conference; Pittsburgh. New York: ASME; 1988. p. 55-63.

[12] Marcelin JL, Abouaf M, Chenot JL. Analysis of residual stresses in hot-rolled complex beams. Computer Methods in Applied Mechanics and Engineering. 1986;56(1):1-16. http://dx.doi.org/10.1016/0045-7825(86)90133-7.

[13] Leighton AK, Perlman AB. Residual stresses in quenched solid and hollow cylinders with application to rail-road axles [doctor dissertation]. Medford: Tufts University; 1994.

[14] Cai Z, Nawafune M, Ma N, Qu Y, Cao B, Murakawa H. Residual stresses in flash butt welded rail. Transactions of Joining and Welding Research Institute. 2011;40:79-87.

[15] Ma N, Cai Z, Huang H, Deng D, Murakawa H, Pan J. Investigation of welding residual stress in flash-butt joint of U71Mn rail steel by numerical simulation and experiment. Materials \& Design. 2015;88:1296-1309. http://dx.doi.org/10.1016/j.matdes.2015.08.124.

[16]American Society for Testing and Materials. ASTM E837: Determining Residual Stresses by the Hole-Drilling Strain. West Conshohocken: ASTM; 2013. https://doi.org/10.1520/E0837-13A.2.

[17] Porcaro RR, Araújo FC, Godefroid LB, Faria GL, Silva LL. Simulação do processo de soldagem elétrica por centelhamento de um aço para trilhos ferroviários. Parte 1 : análise de tensões residuais via elementos finitos. Soldagem e Inspeção. 2019;24:e2412. http://dx.doi.org/10.1590/0104-9224/si24.12.

[18] Mansouri H, Monshi A. Microstructure and residual stress variations in weld zone of flash-butt welded railroads. Science and Technology of Welding and Joining. 2004;9(3):237-245. http://dx.doi.org/10.1179/136217104225012201.

[19]Bauri LF. Soldagem de topo com centelhamento de trilhos ferroviários: caracterização estrutural, propriedades mecânicas e desgaste [Master dissertation]. São Paulo: Universidade de São Paulo; 2019.

[20] Nishikawa LP, Goldenstein H. Divorced eutectoid on heat-affected zone of welded pearlitic rails. Journal of the Minerals Metals \& Materials Society. 2018;71:815-823. http://dx.doi.org/10.1007/s11837-018-3213-5.

[21] American Railway Engineering and Maintenance-of-Way Association. Manual for Railway Engineering. Chicago: AREMA; 2010. Rail.

[22] Tawfik D, Mutton PJ, Chiu WK. Experimental and numerical investigations: alleviating tensile residual stresses in flash-butt welds by localised rapid post-weld heat treatment. Journal of Materials Processing Technology. 2008;196(1-3):279-291. http://dx.doi.org/10.1016/j.jmatprotec.2007.05.055.

[23] Tawfik D, Mutton PJ, Chiu WK. Transient thermal stress analysis on rapid post-weld heat treatments applied to flash butt welded rails. Science and Technology of Welding and Joining. 2006;11(3):326-336. http://dx.doi.org/10.1179/174329306X107629.

[24] Tawfik D, Mutton PJ, Chiu WK. Modifying residual stress levels in rail flash-butt welds using localised rapid post-weld heat treatment and accelerated cooling. Int. Heat Treat. Surf. Eng. 2008;2(3-4):126-130. http://dx.doi.org/10.1179/174951508X429212.

[25] Ringsberg JW, Lindbäck T. Rolling contact fatigue analysis of rails inculding numerical simulations of the rail manufacturing process and repeated wheel-rail contact loads. International Journal of Fatigue. 2003;25(6):547-558. http://dx.doi.org/10.1016/S01421123(02)00147-0.

[26] Porcaro RR, Faria GL, Godefroid LB, Apolonio GR, Cândido LC, Pinto ES. Microstructure and mechanical properties of a flash butt welded pearlitic rail. Journal of Materials Processing Technology. 2019;270:20-27. http://dx.doi.org/10.1016/j.jmatprotec.2019.02.013. 
[27]Porcaro RR, Lima DAP, Faria GL, Godefroid LB, Cândido LC. Microestrutura e propriedades mecânicas de um aço para trilhos ferroviários soldado por centelhamento. Soldagem e Inspeção. 2017;22(1):59-71. http://dx.doi.org/10.1590/0104-9224/si2201.07.

[28] Porcaro RR, Araújo FC, Godefroid LB, Faria GL, Silva LL. Simulação do processo de soldagem elétrica por centelhamento de um aço para trilhos ferroviários. Parte 2: análise dilatométrica e numérica. Soldagem e Inspeção. 2020;25:e2533. http://dx.doi.org/10.1590/01049224/si25.33.

[29] Oliveira BS, Rodrigues LAS, Costa ES, Braga EM, Reis MAL. X-ray diffraction analysis of residual stresses in the premium rails welded by flash butt process. Soldagem e Inspeção. 2020;25:e2529. http://dx.doi.org/10.1590/0104-9224/si25.29.

[30]Nishikawa LP. Soldagem de trilhos ferroviários perlíticos: origem das microestruturas [Master dissertation]. São Paulo: Universidade de São Paulo; 2018.

[31] Ojha S, Mishra N, Jha B. Effect of cooling rate on the microstructure and mechanical properties of a C-Mn-Cr-B steel. Bulletin of Materials Science. 2015;38:531-536. http://dx.doi.org/10.1007/s12034-015-0862-7.

[32] Ordonez R, Isaac Garcia C, DeArdo AJ. Effect of thermomechanical processing and cooling rate conditions on the austenite decomposition behavior in hypereutectoid steels. Materials Science \& Technology Conference \& Exhibition. 2010;10:1327-1335.

[33] Krauss G. Steels: processing, structure, and performance. 2nd ed. Materials Park: ASM International; 2015. http://dx.doi.org/10.31399/asm.tb.spsp2.9781627082655.

[34] Verhoeven JD, Gibson ED. The divorced eutectoid transformation in steel. Metallurgical and Materials Transactions. A, Physical Metallurgy and Materials Science. 1998;29(4):1181-1189. http://dx.doi.org/10.1007/s11661-998-0245-4.

[35] Lewis R, Olofsson U. Wheel-rail interface handbook. Boca Raton: Elsevier; 2009. http://dx.doi.org/10.1533/9781845696788.

[36] International Heavy Haul Association. Guidelines to best practices for heavy haul railway operation: wheel and rail interface issues. 1st ed. Virginia: IHHA; 2001.

[37] Carroll RI, Beynon JH. Rolling contact fatigue of white etching layer: part 1. Crack morphology. Wear. 2007;262(9-10):1253-1266. http://dx.doi.org/10.1016/j.wear.2007.01.003.

[38] Thelning KE. Steels and its heat treatment. London: Butterworths; 1975.

[39] Ariza EA, Martorano MA, Lima NB, Tschiptschin AP. Numerical simulation with thorough experimental validation to predict the build-up of residual stresses during quenching of carbon and low-alloy steels. ISIJ International. 2014;54(6):1396-1405. http://dx.doi.org/10.2355/isijinternational.54.1396.

[40] Bhadeshia HKDH, Honeycombe R. Steels: microstructure and properties. Oxford: Elsevier; 2006. 